\section{UNIVERSITY OF ABERDEEN}

SEEL

\section{Business School}

\section{Department of Economics}

\section{Scottish Experimental Economics Laboratory}

Does Source of Income Affect Risk and

Intertemporal Choices?

Hans K. Hvide and Jae Ho Lee

Discussion Paper in Economics No 15-6

August 2015

ISSN 0143-4543 


\title{
Does source of income affect risk and intertemporal choices?*
}

\author{
Hans K. Hvide ${ }^{\dagger} \quad$ Jae Ho Lee
}

August 20, 2015

\begin{abstract}
Economic theory predicts that consumption and investment choices should not depend on the source of the budget. We test this assumption through conducting two experiments. In both experiments, we divide participants into two groups: those that obtain an endowment through a windfall and those that obtain the same amount through completing a physical effort task. We show that individuals in the hard-earned group make significantly less risky and more patient choices than individuals in the windfall group. We corrobate the existence of source-dependent decision rules through surveying a large and representative sample of individuals. Our findings are consistent with versions of mental accounting theory where mental accounts are linked to source of income. We conclude that consumption and investment behavior are source-dependent, unlike what is assumed by economic theory.
\end{abstract}

Keywords: house money, risk preferences, time preferences, windfall gain.

JEL codes: C91, D14, E21.

${ }^{*}$ Thanks to University of Aberdeen in Scotland and Sogang University in South Korea for providing access to their experimental labs. Thanks to Syngjoo Choi, Euan Phimister, Joseph Swierzbinski, seminar audiences, and in particular to Bertil Tungodden for valuable comments. We gratefully acknowledge financial support from University of Aberdeen (Principal's fund) and the University of Bergen (Småforsk).

${ }^{\dagger}$ University of Bergen. Email: hans.hvide@econ.uib.no. Hvide is also affiliated with CEPR and the University of Aberdeen.

${ }^{\ddagger}$ University of Aberdeen. Email: jhlee@abdn.ac.uk. 


\section{Introduction}

Almost all economic decisions have intertemporal and risk aspects, whether it involves purchasing a car, investing in stocks, or finding a spouse. Standard economic theory attempts to understand such decisions assuming stable preferences and a budget constraint, where decisions can depend on the size of the budget, but the source of the budget, whether obtained through inheritance, a tax break, overtime at work, should not play a role (as long as expectations about future income are held fixed). The purpose of this paper is to provide new evidence on whether source of income affects risk and intertemporal choices.

Why should source of income matter? Folk wisdom, expressed by the proverb "easy come easy go", suggests that money obtained easily, through for example inheritance or a lottery win, is allocated differently, less cautiously and less patiently, than money that is hard-earned. ${ }^{1}$ Field evidence point in the same direction; Souleles $(1999,2002)$ shows that the marginal propensity to save among households was low for the Reagan era tax cuts and refunds. Without a control group, however, it is difficult to know whether other mechanisms such as liquidity constraints or wealth effects played a role. One theoretical tradition consistent with source of income effects on investment behavior is mental accounting theory (e.g., Camerer et al, 2004, Thaler, 2008), where income is split into mental accounts, such as daily expenditures, savings, entertainment, donations, and individuals optimize locally, i.e., inside these accounts. Of course, if income is split optimally into mental accounts, there is no discrepancy between mental accounting theory and standard economic theory. A version of mental accounting theory consistent with source of income effects is when the allocation into mental accounts is linked to the source of the income (Thaler, 1999), as when windfall gains are invested more risky than hard-earned gains. ${ }^{2}$

We wish to test in a controlled environment whether source of income affects investment behavior. The null hypothesis, supported by economic theory, is that source of money has no effect. The alternative hypothesis, supported by evidence and by mental accounting theory, is that individuals are less restrained with windfall money than hard-earned money; more willing to accept risks and more impatient.

To test whether source of income affects investment behavior, we run two separate experiments (on

\footnotetext{
${ }^{1}$ Literature is awash with examples of the human tendency to spend money in a source dependent manner. An early example is from the New Testament, Luke 15, where the younger son of a wealthy man insists on getting his share of inheritance while the father is still alive. The father, unwisely as it turns out, gives in, and the son goes on to squander the fortune on "wild living". Thaler (1999) writes "A few years ago I gave a talk to a group of executives in Switzerland. After the conference my wife and I spent a week visiting the area. At that time the Swiss franc was at an all-time high relative to the US dollar, so the usual high prices in Switzerland were astronomical. My wife and I comforted ourselves that I had received a fee for the talk that would easily cover the outrageous prices for hotels and meals. Had I received the same fee a week earlier for a talk in New York though, the vacation would have been much less enjoyable."

${ }^{2}$ In some formalizations, mental accounting theory has been bridged with loss aversion theory, but the focus has been on different behavioral responses to losses and wins, rather than the source of wins, see e.g., Heath \& Soll (1996) or Barberis \& Huang (2001). See also Lee (2015).
} 
two distinct subject groups). In both experiments, subjects are split into two groups; one group receives an endowment through a windfall gain, and the other group earns the same amount through completing a tedious task (e.g., potato peeling). A key point in the experimental design is that we attempt to pay the "hard-earned" group reasonably well per unit of time, but not excessively; we wish to avoid the pay being perceived as being (partly) a windfall. We then instruct subjects to choose between lotteries that differ along the risk and intertemporal dimensions, using procedures proposed by Holt \& Laury (2002) and Andreoni et al. (2013). For risk taking, the Holt-Laury procedure ranks alternatives in degree of riskiness and subjects choose a switching point; subjects with a higher switching point take less risk. For intertemporal allocation, the Andreoni-Sprenger procedure ranks alternatives on an intertemporal budget line in terms of degree of patience, and subjects choose one of the alternatives.

The main result of the paper is that the windfall group makes significantly more risky and less patient choices than the hard-earned group. The differences are large; for example, three quarters of subjects in the windfall group accept an actuarially fair bet in the first experiment, while the corresponding number for the hard-earned group is one quarter. Assuming common within-group preferences of a particular form allows us to structurally estimate risk and time preferences. This estimation procedure yields risk aversion and discount factor estimates that are significantly different for the windfall and hard earned money groups. We also investigate whether there is heterogeneity of treatment effects depending on, for example, gender and average daily spending or self-reported measures of risk and time preferences. We find no major heterogeneity of treatment effect. For example, we find a similar source dependency across gender.

To further substantiate whether subject behavior is due to source of income effects, we asked the experimental subjects, after completing the experiment, about their preferred choice in a series of hypothetical choice situations involving either a windfall gain or a hard-earned gain. Subjects reported being much more likely to make risky and impatient choices if they receive a windfall (lottery win) than if the same amount of money is hard-earned (part-time job in a grocery store). The effects appear large; for example a question in the survey asks subjects to choose between a nice dinner in a restaurant or top-up a travel card. With earned money, 70.5 percent of subjects said they top-up a travel card. With endowed money, the corresponding number was 20.5 percent. The choices do not appear to be very different when the size of the hypothetical budget is altered.

The experiments and the first survey were run on an undergraduate student population. To assess whether source of income effects are present in the broader population we ran a similar survey on a representative sample of 1000 adults. Also in this survey we find very strong differences across the two groups; individuals that were exposed to the windfall "treatment" make more risky and impatient choices 
than individuals that were exposed to the hard-earned treatment. Based on these results, we conjecture that source of income effects documented in the experiments extend beyond the university undergraduate population.

Our work is related to several strands of the literature. First, motivated by Friedman's permanent income hypothesis, a large literature has studied consumption choices following windfall gains in the field. One example is the work by Souleles $(1999,2002)$ cited above. Other studies suggest a link between source of income and which budget the income is allocated into, consistent with mental accounting as expressed in Thaler (1999). For example, Kooreman (2000) shows that spending on children clothing is much more sensitive to changes in child allowance than to other income sources, and Beatty et al. (2011) use regression discontinuity methodology to show that the UK winter fuel payment, a cash grant, is disproportionately spent on heating; examples of the so-called flypaper effect in public finance (Jacoby, 2002). In contrast to this body of work, we show in a controlled environment that subjects make less risky and more patient decisions with hard earned money than with windfalls, holding the transfer to each group constant.

Second, recent experimental work investigates whether subjects are less "cooperative" with money obtained after an effort task than with money received through a windfall. Cherry et al. (2002) shows that subjects playing a dictator game are less generous with money obtained after a mental task (answering 10 out of 17 GMAT questions correctly) than with a windfall gain. Spraggon \& Oxoby (2009) finds the opposite result in a public good game, and Cherry et al. (2005) find no effect in a public good game. ${ }^{3}$ This literature has shown that social preferences are source dependent. We complement this literature by looking at source dependence in other preference domains.

Third, one of the oldest findings of behavioral economics is the endowment effect, where individuals value objects more highly when they possess them than when they do not (Knetsch, 1989, Camerer et al., 2004). Cardenas et al. (2014) and Morrison \& Oxoby (2013) study the effect of the timing of windfalls on risk and intertemporal decisions, the idea being that subjects may value endowments received weeks before the experiment differently than an endowment received immediately before the experiment (one issue with this empirical strategy is that subjects in the early endowment group may spend it prior to coming to the lab). Cardenas et al. (2014) does not find a difference in risk taking among the early and late recipient groups. Morrison \& Oxoby (2013) finds that the group that receives the endowment prior

\footnotetext{
${ }^{3}$ Cappelen et al. (2010) find that people think it is more fair to have inequality if inequality is caused by level of effort rather than luck. Corgnet et al. (2014) show that trading volume in an experimental asset market is higher with windfall money than with earned money. However, due to the complicated strategic interaction in this setting, it is difficult to relate it to individual preferences; more active trading may be due expectation of higher (risk-adjusted) returns rather than individuals becoming more tolerant to risk per se. We avoid strategic interaction in order to isolate source of budget related determinants of individual behavior.
} 
to the date of the experiment (one week before) exhibit more patient choices than those that receive the endowment on the date of the experiment. In contrast, we study the effect of how the endowment is earned, through a windfall or through hard work, and hold constant the timing of transfer. ${ }^{4}$

Fourth, a large experimental literature studies whether individuals react differently to gains or losses in experiments. For example, Thaler \& Johnson (1990) shows that prior gains leads to riskier choices than prior losses ("house-money effect"), while this pattern can be reversed if the subjects get the opportunity to bet on long shots that can make them break even ("break-even effect"). Common for these experiments is that wealth or income effects may explain at least part of the behavior. In contrast, we consider a setting where the two groups have the same initial endowment, and compare the effect of the endowment being received through a windfall or through hard work.

Fifth, a long tradition in accounting and finance purports that managers tend to be myopic in their investment decisions, and thereby waste long-run shareholder value. Several explanations have been offered, including takeover pressure (Stein, 1988), equity-based compensation contracts (Kaplan \& Minton, 2011), and earnings management (Stein, 1989). Our findings suggests that one reason for myopia might be imperfect managerial response to cash flow windfalls. For example, Andrén \& Jankensgård (2015) show that oil industry firms that were not financially constrained increased their cash flow - investment sensitivity after the mid 2000s windfall due to increased oil price, and attributes this to agency problems, much along the lines of Jensen (1986) free cash flow theory. Investment decisions that are source dependent is an alternative, and to our knowledge novel, explanation of this finding.

\section{Experimental design}

We ran two experiments, one on risk choices and one on intertemporal choices. Each experiment consisted of two stages. In the first stage, subjects were split into two treatment groups; the "windfall group" and the "hard-earned group". The windfall group received an endowment simply by showing up, and the hard-earned group earned the same amount through peeling potatoes or making envelopes. The participants in the hard-earned groups were given a performance target (peeling 25 potatoes or making nine envelopes), and received the endowment if they meet the target within 30 minutes. ${ }^{5}$ A key point in the experimental design is that the "hard-earned" group gets reasonably well paid, $5000 \mathrm{KRW}$ in risk choice

\footnotetext{
${ }^{4}$ While the analysis of timing of windfalls is their main focus, Morrison \& Oxoby (2013) contains a pair of treatments where the 50 subjects either received USD 40 through a windfall, or after completing 10 out of 20 GRE questions correctly (all subjects completed the task and received USD 40). Morrison \& Oxoby (2013) do not find a difference in the elicited discount rates between these two groups. We suspect this could be because subjects did not necessarily find correctly answering 10 GRE questions for USD 40 "hard work" but rather a windfall.

${ }^{5}$ In one session in HL experiment, eight subjects were given a corn-plucking task, where the subjects manually extract any corn kernel from two ears of corn.
} 
experiment or $£ 10$ in intertemporal choice experiment, but not excessively; we wish to avoid the pay being perceived as being (partly) a windfall. $5000 \mathrm{KRW}$ corresponds to about half-day of expenditure for the subjects and $£ 10$ corresponds to about one day of expenditure for the subjects. ${ }^{6}$ The relatively short working time (35 minutes in total) was chosen to avoid any fatigue that could lead to a bias.

In the second stage, we investigated whether there were differences in risk and intertemporal choices between the two treatment groups. The risk choices experiment is based on Holt \& Laury (2002) and the intertemporal choice experiment is based on Andreoni et al. (2013). For risk taking, the Holt-Laury procedure ranks alternatives in degree of riskiness and subjects choose a switching point; subjects with a higher switching point take less risk. For intertemporal allocation, the Andreoni-Sprenger procedure ranks alternatives on an intertemporal budget line in terms of degree of patience, and subjects choose one of the alternatives. ${ }^{7}$ We analyze whether there are significant differences in choices between the two treatment groups.

\subsection{Subject pool}

The participants in the experiments were recruited from the student population of University of Aberdeen in Scotland (the intertemporal choice experiment) and from Sogang University in South Korea (the risk choice experiment). All participants were recruited with the same set of procedures. They were invited to take part in a research project but were not told the purpose of the experiment. They were promised a minimum earnings and told a possible maximum earnings from participation. Participants were asked to pick three alternative sessions, and were randomly allocated between sessions.

Participants in the risk choice experiment were paid in cash at the end of experiment whereas participants in the intertemporal choice experiment were told that they would receive money by online bank transfer and were only allowed to participate if their bank account allowed for this. ${ }^{8}$

We ran 14 sessions with in total 144 subjects; 83 in the risk choice experiment and 61 in the intertem-

\footnotetext{
${ }^{6}$ Converting the $5000 \mathrm{KRW}$ or $£ 10$ to an hourly rate is difficult because subjects also spent time coming to the experiment, listening to instructions etc. In addition to the $5000 \mathrm{KRW}$ or $£ 10$ they also received a participation fee of $10000 \mathrm{KRW}$ (= approx. $\$ 10$ ) and $£ 3$ (= approx. \$4.5), respectively. The participation fee in the risk experiment is larger than that of intertemporal allocation experiment in the UK. The larger participation fee was paid in risk experiment foremostly in order to match typical earnings in SEE Lab (Sogang Experimental Economics Laboratory) and encourage participation.

${ }^{7}$ Andreoni et al. (2013) is a discrete choice version of the original Andreoni and Sprenger (2012). Andreoni \& Sprenger (2012) used a computer interface to allow subjects to choose any alternatives (i.e., allocations) on an intertemporal budget line. As our experiments involved a physical task, using a room with computers, like a laboratory, was less practical, and we therefore opted for a paper-based experiment using a discrete choice set rather than a continuous choice set as in Andreoni \& Sprenger (2012).

${ }^{8}$ In the intertemporal choice experiment, we used the faster payment system. This is an electronic payment system which allows people to receive money within a few hours. Although almost all current accounts in the UK retail banks automatically allows receiving faster payment, the participants were still asked to check on the UK payment council and give us confirmation (http://www.paymentscouncil.org.uk/resources_and_publications/sort_code_checker).
} 
poral choice experiment. Table A1 summarizes the sociodemographic characteristics of the risk choice experiment (Panel A) and for the intertemporal choice experiment (Panel B). Within each experiment, the treatment groups are reasonably balanced, with the exception of the "Smoking", "Other Participants", and "Confidence" variables in the risk choice experiment. ${ }^{9}$ In the analysis we take into account this possible non-randomness in recruitment, but find no significant effect except for the "Confidence" variable. Understandably, subjects who were not confident of receiving payments were less risk-averse, consistent with previous literature. For example, Holt \& Laury (2002) find that the subjects were significantly less risk-averse in the hypothetical experiment than in the real experiment. It is plausible that subjects who do no believe they would be paid may view the experiment as hypothetical.

\subsection{The experiments}

At the beginning of the experiment, participants in both the windfall group and the hard-earned group were provided with an instruction sheet, which gave a complete description of the decision-making problems and how earnings are decided from subject's decision-making, as described below. Participants in the windfall group were told that they were given some money simply for showing up and that they were going to participate in the next phase (the decision-making problem) with this money. Similarly, participants in the hard-earned group were also told that the experiment consisted of two stages, where the first stage consisted of earning a starting payment from a real physical task and the second stage involved decision-making problem phase with their starting payment. ${ }^{10}$ After the instruction session, the participants in the windfall group went on to the decision-making problem whereas the participants in the hard-earned group performed a physical task and earned the starting payment before they went on to the decision-making problem. After five minutes practice time, the hard-earned group would earn a starting payment of $£ 10$ or $5000 \mathrm{KRW}$ by either peeling 25 potatoes (intertemporal choice experiment) or making nine envelopes (risk choice experiment), respectively, during in 30 minutes. They were told that the completed work would not be wasted but would be used for real. ${ }^{11}$ After the production phase, the experiment proceeded as for the windfall group. There was only one participant (in risk choice experiment) who failed meet the target.

In the risk choice experiment, the decision-making problem asks whether subjects want to keep their

\footnotetext{
${ }^{9}$ The participants in the risk preferences experiment is older on average (23.5 years) than in the intertemporal choice experiment (20.9 years). The 'Korean age' is different to western reckoning. In Korea, newborns start at the age of 1 year and everyone gets a year older on New Year's day regardless of their birthdays. Thus, Korean age is always either one or two years older than Western age.

${ }^{10}$ For a full set of instructions, please see the online Appendix.

${ }^{11}$ The initial plan was to have the same physical task (peeling potatoes) in both experiments, but this turned out infeasible because the second experiment was conducted in South Korea in the summer, when the weather conditions are very hot and humid, which cause vegetables to rot. Therefore the envelope task was used in the second experiment.
} 
initial endowment or participate in a lottery with it. The lottery pays either $11000 \mathrm{KWR}$ (equivalent to $\$ 11$ ) or $200 \mathrm{KRW}$ (equivalent to \$0.2). The subjects make nine decisions, where each decision differs in the probability of receiving favorable outcome. Subjects with a higher switching point take less risk. At the end of experiment, one of nine decisions is randomly selected for actual payments and the subjects are paid in cash. ${ }^{12}$

In the intertemporal choice experiment, the procedure asks subjects to allocate their initial endowment between two points in the future, $t$ and $t+k$, subject to the intertemporal budget constraint,

$$
x_{t}+\frac{x_{t+k}}{p}=m
$$

where $m$ is the initial endowment, $x_{t}$ is the earlier payment, $x_{t+k}$ is the later payment, and $p$ is the interest rate, where $p \in\{1.0,1.1,1.2,1.3,1.4,1.5,1.6,1.7\}$. There were two earlier payment dates (day of experiment, 6 weeks after the experiment) and three later payment dates ( 6 weeks, 12 weeks and 18 weeks after the experiment). The gist of the experiment is to, for varying interest rates, ask subjects to allocate their budget $m$ into payment at date $t$ or date $t+k$. Subjects that tend to allocate more to date $t+k$ exhibit more patience. In the experiment, subjects faced a total of 36 different intertemporal budget constraints and made 36 intertemporal decisions. One of these decisions is randomly selected for the actual payment.

One of the most important aspects of intertemporal choice experiment is to equalize the credibility of payments over different dates. In order to do so, previous experiments have used 'front-end-delay' payment where the earliest payment date is anything from a day after the experiment to as long as a month. This is done in order to remove the subject's temptation to choose immediate payment, simply because the payments in a distant future do not seem credible. ${ }^{13}$ Therefore, we paid participants by faster payment, which is an electronic payment system which allows people to receive money within a few hours. Faster payment would not only equalize the credibility of payments over different dates, but also maintains the immediacy of payments that characterize the present-bias. To minimize any unexpected difference in transaction costs between two dates, two equally sized participation fees of $£ 1.50$ are also paid. One participation fee was added to the earlier date earnings and the other participation fee was

\footnotetext{
${ }^{12}$ In the original Holt-Laury procedure, the participants face a choice between two uncertain lotteries. We chose one certain and one uncertain lottery to avoid forcing subjects to participate in the lottery with their own money. A sure gain option could lead to certainty bias (Kahneman \& Tversky, 1979). In a separate experiment (not reported) at the same university, we replicated the standard Holt \& Laury (2002) experiment using another subject sample from the same university. Here we found no evidence of a certainty bias.

${ }^{13}$ Another solution is to post the payment (e.g., cheque) where the mail delivery was usually made after the day of the experiment. However, as discussed in Dohmen et al. (2012), a potential drawback of delaying the earlier date payment is losing immediacy of payment. This can be a problem, especially if the experiment is designed to test the present-bias.
} 
added to the later date earnings. This prevents, for example, a subject choosing a corner solution simply because they prefer to receive a single payment rather than two separated payments.

\section{Results}

\subsection{Risk choices}

In each decision-making problem, the subjects were given a table of nine decision rows. In each decision row, the participants are asked to choose between the riskless Option A and a lottery, Option B. The lottery in decision row 1 is the most risky and the lottery in decision row 9 is the least risky. The degree of risk-taking is inferred from the switching point, i.e., the row where a subject switches from choosing Option A to choosing Option B. ${ }^{14}$ The following figure plots the choices made by the two groups.

(FIGURE 1 ABOUT HERE)

The figure displays the proportion of times Option A (the riskless choice) was chosen at each decision row for each group. The horizontal axis is the row number and vertical axis is the percentage where Option A was chosen. A risk-neutral individual would switch to Option B at row five, as indicated by the green line. The blue line displays choices for the windfall money group and the red line displays the choices for the hard-earned money group. The difference between the two groups is striking; the proportion of Option A in the windfall group drops markedly between row four and five while the individuals in the hard-earned group switches from Option A to Option B much more gradually. Many subjects in the hard-earned group chose riskless choice even when the expected value of the lottery becomes considerably larger than retaining money.

\section{(TABLE 1 ABOUT HERE)}

We now collect one number from each individual, their switching point $s_{i}$, and regress $s_{i}$ on treatment status, $T_{i}$, where $T_{i}=1$ for the hard-earned group and 0 if not, and other characteristics. Table 1 displays the regression results. The first column reports the results of a regression of $s_{i}$ only on $T_{i}$, i.e., a simple $t$-test between the treatment groups, and the other columns add individual sociodemographic characteristics. Across the columns, being in the hard-earned group is associated with about 1.6 higher switching point, i.e., less risky choices. We note that self-reported willingness of risk-taking from the survey is associated with risk choices in the experiment. Subjects who are generally more risk-seeking

\footnotetext{
${ }^{14}$ Two participants out of 82 made inconsistent choices and were excluded from the analysis. Further two subjects are also dropped because they did not complete the survey questions, leaving a sample of 78 .
} 
are also more risk-seeking in the experiment. ${ }^{15}$ In the regression, we take into account possible nonrandomness in recruitment, but find no significant effect except for the "Confidence" variable. There were seven subjects who said they were not confident of receiving payments and it is plausible that they may view the experiment as hypothetical. These subjects were significantly more risk-seeking on average, which is consistent with previous literature; Holt \& Laury (2002), for example, find that the subjects were significantly more risk-seeking in the hypothetical experiment than in the real experiment.

We also investigate whether there is heterogeneity of treatment effects (i.e., hard-earned group) between, for example, gender, average daily spending, age, subject's major or self-reported measures of risk preferences. We find no heterogeneity of treatment effect except for trust and exercise; earning money has a significant negative effect on subject's switching point for subjects who easily trust strangers as compared to subjects who do not trust strangers (i.e., a weaker positive effect from earning money). Please see Appendix Table A3 for regression results.

To structurally estimate degree of risk aversion, we adopt the procedure of Harrison \& Rutstrom (2008). Assume that the subjects have CRRA (Constant Relative Risk Aversion) utility functional form,

$$
U(x)=x^{1-r}
$$

where $r$ is the coefficient of CRRA. A higher $r$ is associated with higher risk aversion. Furthermore, we assume that the CRRA coefficient $r$ is determined by the following linear equation,

$$
\hat{r}=\hat{r}_{0}+\hat{r}_{1} T_{i}
$$

where the treatment $T_{i}=1$ if hard-earned money, and $T_{i}=0$ if windfall money. We assume that errors are normally distributed and structurally estimate $\hat{r}_{0}$ and $\hat{r}_{1}$ using maximum likelihood. ${ }^{16}$

\section{(TABLE 2 ABOUT HERE)}

Table 2 reports the structural estimation results. The first column of Table 2 displays the estimation results from Luce's (1959) choice probabilistic ratio from the full sample of observations. The average CRRA coefficient was 0.02 in the windfall money group, i.e., close to risk neutral, and 0.45 in the hardearned group, i.e., risk-averse. Earning money increases the CRRA coefficient by 0.43 on average and

\footnotetext{
15 The sociodemographic controls that is statistically significant (at the 10\% level) are exercise, postpone, and trust. Exercise is a dummy variable that takes a value of one if a subject exercise regularly, and zero if not, and Postpone is a dummy variable that takes a value of one if a subject often postpone duties, and zero if not. Trust is the degree of trusting strangers in general. Consistent with previous literature (e.g., Anderson and Mellor, 2008; Barsky et al., 1997; Croson and Gneezy, 2009; Dohmen et al., 2005), being a female or non-smoker is associated with more risk averse choices, but in our case not statistically significant.

${ }^{16}$ Please see Appendix for full description of econometric method.
} 
the difference is statistically significant $(p \prec 0.01) .{ }^{17}$

Column (2) - (4) of Table 2 are robustness checks. Column (2) and Column (3) in Table 2 is the robustness check on the unbalanced variables between the treatment groups. Column (2) in Table 2 displays results excluding 7 subjects who said in the survey that they were not confident that they would receive the payments described in the instructions. Interestingly, 6 out of these 7 subjects were from the windfall group, suggesting that subjects were more skeptical about receiving payments when they easily obtained money. Column (3) of Table 2 displays results excluding 32 subjects ( 21 subjects in the windfall group and 11 subjects in the hard-earned group) who personally knew any other participants within the same or previous sessions. Consistent with the regression results, the source of income effect was still robust in both Column (2) and (3). A half of the subjects have an experience in participating economics experiments before participating ours. Column (4) of Table 2 displays results excluding these 39 subjects but the results remain same. ${ }^{18}$

\subsection{Intertemporal choices}

In each decision-making problem, there are six options on a budget line defined by (1) and subjects pick their most-preferred option. The options are ranked in degree of patience, where Option 1 is the least patient option (i.e., allocation of all endowment into the earlier date) and Option 6 is the most patient option (i.e., allocation of all endowment into the later date). ${ }^{19}$ The following figure gives an overview of the choices made by the two groups.

\section{(FIGURE 2 ABOUT HERE)}

Figure 2 compares the mean allocation to the later date against the interest rate for the windfall group (blue line) and the hard-earned group (red line). As expected the slopes of both lines are increasing; both groups increase their allocation to the later date as the interest rate increases. Again the difference between the two groups is striking: for most interest rates, the mean number of allocation to the later date is higher in the hard-earned group than in the windfall group, suggesting that subjects are more patient in the hard-earned group. Clearly source of income effects are not all-powerful: when the interest

\footnotetext{
${ }^{17}$ The estimated CRRA coefficient in the hard-earned group is higher than that of Holt \& Laury's (2002) 0.27 and the estimate in the windfall group is substantially lower than this. It is interesting to observe "risk-neutrality" in the windfall group as the "risk-aversion" is often observed in laboratory experiments using Holt-Laury estimation.

${ }^{18}$ For example, Guillen and Veszteg (2012) finds that previous experience in participating experiment could lead to selection bias (e.g., males are more likely to participate again), but we find no evidence of similar selection bias in our sample.

${ }^{19}$ As in Andreoni \& Sprenger (2012) and Andreoni et al. (2013) we dropped two subjects who do not have any variation with their choices because parameter estimation for these subjects is not feasible. The results remain same if these two subjects are included.
} 
rate becomes very high, most subjects in both groups prefer the most patient option. For example, the fraction of Option 6 (i.e., most patient) was chosen when the daily interest rate is one basis point or higher is $84.5 \%$ in the windfall group and $91.7 \%$ in the hard-earned group.

\section{(TABLE 3 ABOUT HERE)}

Table 3 displays the regression results of the allocation to the later date, $l_{i}$, on treatment status, $T_{i}$, where $T_{i}=1$ for the hard-earned group and 0 if not. The first column reports the results of the regression of $l_{i}$ only on $T_{i}$, i.e., a simple $t$-test between the treatment groups, and the other columns add individual sociodemographic characteristics. Across the columns, being in the hard-earned group is associated with about $£ 2.40$ more of the budget allocated to the later date, i.e., more patient choices. Somewhat surprisingly self-reported degree of patience is associated with less patient choices in the experiment, but not statistically significant. ${ }^{20}$

Understandably, the participants who have some specific reason for their decision-making other than monetary rewards are less patient as the majority of reasons were the urgent need of money. We also investigate whether there is heterogeneity of treatment effects (i.e., hard-earned group). We find no major heterogeneity of treatment effect except for, for example, "Earned $\times$ Course" interaction term. For example, we find that earning money has a significant negative effect on the later date allocation for subjects whose major is business school related course of degrees as compared to non-business school students (i.e., a weaker positive effect from earning money). ${ }^{21}$

The Andreoni-Sprenger procedure allows us to structural estimation of a discount rate, present-bias and utility curvature. ${ }^{22}$ The following table reports the results of a structural estimation using non-linear least squares.

\section{(TABLE 4 ABOUT HERE)}

Table 4 reports estimates of aggregate annual discount rate, present bias parameter, and utility curvature for each group. The first column of Table 4 reports estimates from the full sample of 59 subjects,

\footnotetext{
${ }^{20}$ In some of the columns, self-reported risk taking is associated with less patience, significant at 5\% level. Also, the participants who knew other participants within the same session or in the previous session were less patient, significant at $10 \%$ level. Consistent with previous literature (e.g.,Coller and Williams, 1999, Chabris et al., 2008, Dohmen et al., 2011), being a female or non-smoker is associated with more patient choices, but in our case not statistically significant.

${ }^{21}$ In one of the columns, hard-earned group subjects who track expenses is associated with less patient choice, significant at $10 \%$ level. Please see Table A4 in the appendix for the detail.

${ }^{22}$ Unlike more commonly used procedures such as Coller \& Williams (1999), we used Andreoni-Sprenger procedure. The problem with Coller \& Willams (1999) is the assumption of linear utility, which could bias the estimated discount rate upwards with concave utility. Andersen et al., (2008) propose a joint estimation strategy to control for utility curvature, but requires two separate tasks; one for curvature and one for discount rate, to estimate the discount rate. Rather than requiring two separate tasks, the Andreoni-Sprenger procedure estimates parameters from a single task.
} 
using non-linear least squares. ${ }^{23}$ The results confirm a significant source of income effect in aggregate intertemporal choices. The subjects in the hard-earned money group are significantly more patient than the participants in the windfall money group; the average annual discount rate is $124.2 \%$ in the windfall money group and $38.7 \%$ in the hard-earned money group, the difference is $85.5 \%$ which is statistically significant. ${ }^{24}$ Contrary to Andreoni \& Sprenger (2012) and Andreoni et al., (2013), but consistent with e.g., Frederick et al. (2002), we find a statistically significant evidence of present-bias. ${ }^{25}$ This holds for both treatment groups (the difference between two groups is insignificant). We can also note that the aggregate curvature is close to linear in both groups. The utility curvature is 0.861 in the windfall money group and 0.866 in the hard-earned money group, and the difference between two groups is statistically insignificant.

The experimental design allowed for four interior solutions to the choice problem, but about $82 \%$ of actual choices are corner solutions. 23 (out of 59) participants have no interior solutions in all 36 budgets. Treatment assignment has relatively little impact on the probability of choosing interior solutions; the windfall group makes $76.3 \%$ corner choices, and the hard-earned group makes $87.1 \%$ corner choices. $^{26}$

The large fraction of corner choices means that the use of non-linear least squares estimation is problematic (Andersen et al., 2014). As alternative regression strategy, we also used (1) two-limit Tobit, and (2) ordered logit. The results are very similar. Column (3) of Table 4 reports the results from twolimit Tobit, where the subject's decision is bounded by Option 1 (i.e., zero allocation into the later date) and Option 6 (i.e., zero allocation into the earlier date). ${ }^{27}$ We still find a significant source of income effect. Table A2 reports the marginal effects of earning money on the probability of choosing each option in each problem set (i.e., each $(t, t+k)$ combination) from ordered logit. The probability of choosing the earlier date corner solution significantly decreases with the hard-earned money but the probability of choosing the later date corner solution significantly increases with the hard-earned money, suggesting higher degree of patience with the hard-earned money.

\footnotetext{
${ }^{23}$ Assuming a time-separable quasi-hyperbolic utility functional form, subject's intertemporal allocation between the two dates is the solution to the standard utility maximization problem where the demand equation for the later date allocation can be derived from the first order condition. Following Andreoni et al. (2013), we apply non-linear least squares (NLS) to this demand function for parameter estimation. See Appendix for full description of estimation strategy.

${ }^{24}$ The estimated discount factor in the hard money group is similar to that of Andreoni \& Sprenger (2012) but lower than the estimates in Andreoni et al., (2013). The estimated discount rates in the windfall money group is substantially higher than the estimate of Andreoni \& Sprenger (2012) or Andreoni et al., (2013).

${ }^{25} \mathrm{Kuhn}$ et al. (2014) also uses a bank transfer system to pay subjects and find a significant present-bias effect.

${ }^{26}$ Although the probability of choosing corner solutions in the hard-earned group is higher than that of windfall group, we cannot conclude that either the hard-earned or windfall group makes noticeably more or less corner choices than what has been observed in previous literatures. Andreoni and Sprenger (2012) obtained 70\% corner solutions. In a similar discrete design to our, Andreoni et al., (2013), obtained 88\% corner solutions. The difference in two treatment groups is more prominently observed in the nature of corner solutions. About $46.4 \%$ of total corner solutions was the earlier date corner solutions in the windfall group, but $74.9 \%$ of corner solutions was the later date corner solutions in the hard-earned group.

${ }^{27}$ For full description of econometric model, please see the Appendix.
} 


\subsection{Surveys}

To further substantiate that source of income effects are real, we conducted a survey on the 78 participants in the risk taking experiment. The survey asked about preferred choice in a series of hypothetical choice situations involving either a windfall gain or a hard-earned gain. We also included questions that were designed to elicit source dependency effects on individual social preferences that have been observed in previous research (Cherry et al., 2002).

\section{(TABLE 5 ABOUT HERE)}

Panel A in Table 5 summarizes the results of the survey. Consistent with the experimental results, the subjects reported being much more likely to make risky and impatient choices if they receive a windfall (lottery win) than if the same amount of money is hard-earned (part-time job in a grocery store). For example, a question in the survey asks subjects to choose between a nice dinner in a restaurant or topping up a travel card. More patient subjects would choose to top-up a travel card. With earned money, 70.5 percent of subjects said they would top-up a travel card but the corresponding number was only 20.5 percent with lottery winnings. The subjects were also more risk-averse with the earned money. For example, when asked between a cheaper non-refundable and a more expensive refundable holiday packages, more subjects chose refundable package with the earned money than with the lottery winnings. We observe a similar pattern in the subsequent questions when the size of the hypothetical budget and the goods in the question is altered. Consistent with Cherry et al. (2002) we also observe that the subjects are more generous with the lottery winnings.

The experiment and survey were run on an undergraduate student population. In order to assess whether source of income effects of the type documented are present in a broader population we ran a similar survey, online, on 1000 adults from Norway. Panel A in Table 5 summarizes the results of the survey. One half of these were randomly allocated to the "windfall group" and answered questions regarding the use of money obtained through a windfall (winning an amount due to being customer 100,000 in a grocery store), and the other half were allocated to the "hard-earned group" and answered questions regarding the use of funds obtained through a part-time job. We again find strong differences across the two groups; individuals that were exposed to the windfall "treatment" report more impatient choices than individuals that were exposed to the hard-work treatment. We observe a similar pattern of source dependency in different demographic groups such as age, gender, income, region, education, and the number of children. Thus, as far as we are able to assess, it appears that source of income effects extend beyond the university undergraduate population. ${ }^{28}$

\footnotetext{
${ }^{28}$ Contrary to the findings in the first survey, we find that windfall subjects are more likely to choose are fundable holiday
} 


\section{Conclusion}

\subsection{Discussion}

The main message of the paper is that source of income matters for investment decisions; money that are obtained through a windfall gain tends to be invested more riskily and less patiently than money that is obtained through work. This finding, which appears both strong and robust in the lab environment, stands in contrast to standard economic theory, where choices can depend on the size of the budget but the source of the budget should not matter.

There are three main interpretations of our findings. First, our findings can be interpreted as a treatment effect on preferences, i.e., preferences being endogenous and determined by the source of money. ${ }^{29}$ Alternatively, we can think of preferences as being stable but source-dependent (state-dependent preferences), as in mental accounting theory. ${ }^{30}$ Here the "treatment effect" is to shift the consumer into a state where his preferences are different than in the old state. A third interpretation is that the individuals have a stable set of preferences, but that treatment can induce investment mistakes. ${ }^{31}$ Perhaps most plausibly we can think of choices under the hard earned treatment as better reflecting "true" preferences (if earned money are closer to real-life experience than windfall money), and choices under the windfall treatment as reflecting true preferences plus investment mistakes. Under this interpretation, subjects would presumably have invested more patiently and cautiously with more experience or better education about investment choices. Our findings do not allow us to distinguish between these three interpretations; our contribution is to show that source of income affects investment behavior.

A key point in our experimental design has been that participants complete a tedious task at a "salary" that is generous but not too generous. The motivation for this is that we want to mirror real-life situations as closely as possible, and avoid that the hard-earned treatment is just a slightly less generous windfall than the windfall treatment. ${ }^{32}$ Letting subjects perform a physical, time-consuming task in the lab leads to interpretational issues. For example, it is possible that part of the differences we find between the hardearned and the windfall groups can be explained by fatigue in the hard-earned group. Evidence suggests that fatigue leads to a "default bias" i.e., a preference for default options (Augenblick \& Nicholson, 2015,

package. This could be because a positive effect on the propensity to consume outweighs the increased risk effect.

${ }^{29}$ Gary Becker is often associated with the view that preferences are stable. But this is not the full picture; Becker (1996) states that "[... modern economics has lost a lot by completely abandoning the classical concern with the effects of the economy on preferences and attitudes" (Becker, 1996, pp. 19-22).

${ }^{30}$ Our results are also consistent with prospect theory if we assume that hard-earned money increases the reference point more than windfalls. Our experiment does not really allow for a test of prospect theory, and was not designed as such.

${ }^{31}$ For example, there is a considerable literature starting with Kagel \& Levine (1986) on overbidding in common value auctions. Overbidding is usually attributed to cognitive errors, not due to changes in preferences.

${ }^{32}$ The extant literature that uses effort tasks in experimental settings tends to get ambiguous results. For example, Cherry et al. (2005) find no effect in a public good provision game, while Spraggon \& Oxoby (2009) finds a negative effect of work. 
Danziger et al, 2011). We can test for default bias in the risk experiment by investigating whether there are differences between hard-earned and windfall groups with respect to choosing either cornerpoints or the middle option of the menu, the presumably most likely default options. We find that the frequency to which the default option is chosen does not differ between treatment and control groups. In the intertemporal choice experiment, the subjects in the hard-earned group make more corner solutions than the windfall group. The majority of corner solutions in the hard-earned group were the later date corner solutions whereas the majority of corner solutions in the windfall group were the earlier date corner solutions. It is unclear why default bias should lead to a differnt pattern of corner solutions between the two groups, and it is not clear to us how to interpret this result. Our results do not appear to be driven by fatigue in the hard-earned group.

Another possibility is that subjects in the hard-earned group behave differently because they have spent more time in the lab, and had more opportunity to "settle in" and discover their true preferences. For example, Plott (1996) proposes a "discovered preference hypothesis", suggesting that responses in experiments "reflect a type of internal search process in which subjects use paid practice rounds along with trial and error to 'discover' what their preferences are." It is unclear to us why settling in should lead to less risky and more patient choices, and not the reverse, but we cannot exclude the possibility that discovered preferences can partially explain our results.

\subsection{Research implications}

Our most important research implication is that investment decisions can depend on the source of the funds, in addition to the available investment opportunities. This finding could explain, for example, why the marginal propensity to consume tend to be high for tax cuts; if tax cuts are associated with a high discount factor then individuals would consume a higher fraction of it than other income.

In future research, one could investigate whether our findings extend to the quality of investment decisions, i.e., whether individuals tend to make more investment mistakes with windfall money than with hard-earned money. Investment mistakes is of substantial policy interest in the household finance area, where numerous findings suggest that the behavior of individual investors differ in several respects compared to the recommendations of portfolio theory predicts. ${ }^{33}$ It is possible that some of this erratic behavior occurs because of effects from making a prior windfall gain, a hypothesis that to our knowledge has not been tested.

\footnotetext{
${ }^{33}$ For example, individual investors tend to sell winners and keep onto losers (Odean, 1998), exhibit a within-industry bias (Doskeland \& Hvide, 2011), and trade too much (Odean, 1999, Barber \& Odean, 2000), and tend to behave less than optimally when refinancing their mortgages (Andersen et al., 2015).
} 
A limitation of our study is that although we believe mental accounting is useful to understand our results, we are not aware of formal models of mental accounting that include source of income. For example, Thaler (2008) contains a formal model which contains some elements of the discussion from Thaler (1999), but does not include source dependency. It would be of interest for future theoretical research on mental accounting to accommodate a notion of source dependency, thereby possibly also refining future empirical tests.

The most important managerial implication of our work is to highlight the psychological tendency to make investment decisions that depend on source of income. Such behavior, if it translates to managers, potentially destroys shareholder value, and managers should consider self-testing and debugging their decision rules to get rid of this tendency.

\section{Appendix: Econometric methods}

This Appendix describes the econometric methods used for structural estimation in Table 2 and Table 4. To structurally estimate the degree of risk aversion in Table 2, we adopt the standard procedure of maximum likelihood approach of Harrison and Rutstrom (2008), as described in Subsection 5.1. For structural estimation of time-preferences in Column (1) of Table 4, we adopt the least square estimation approach of Andreoni and Sprenger (2012) and Andreoni et al. (2013), as described in Subsection 5.2. In Column (3) of Table 4 we also used two-limit Tobit model as a robustness check, following Andreoni and Sprenger (2012). Subsection 5.3 provides description of this model.

\subsection{Table 2: Structural Estimation of Risk-aversion}

To structurally estimate degree of risk aversion, we adopt the procedure of Harrison and Rutstrom (2008). Assume that the subjects have CRRA (Constant Relative Risk Aversion) utility functional form,

$$
U(x)=x^{1-r}
$$

where $r$ is the coefficient of CRRA. A higher $r$ is associated with higher risk aversion. Furthermore, we assume that the CRRA coefficient $r$ is determined by the following linear equation,

$$
\hat{r}=\hat{r}_{0}+\hat{r}_{1} T_{i}
$$

where the treatment $T_{i}=1$ if hard-earned money, and $T_{i}=0$ if windfall money. Following Holt and Laury (2002) we used Luce's (1959) probabilistic ratio to define the latent index $\nabla E U$, where $E U_{i}$ is 
the expected utility for each option.

$$
\nabla E U=\frac{E U_{\text {Lottery }}^{\frac{1}{\eta}}}{U_{\text {Lottery }}^{\frac{1}{\eta}}+U_{\text {Riskless }}^{\frac{1}{\eta}}}
$$

The noise parameter $\eta$ captures any deviation from the expected utility maximization choice. As $\eta \longrightarrow 0$, the person will always choose the option with higher expected utility. As $\eta \longrightarrow \infty$, the probability converges to $\frac{1}{2}$, and choice becomes random. This latent index is then linked to the observed choice and the conditional log-likelihood becomes

$$
\left.\ln L\left(r_{0}, r_{1}, \eta \mid y\right)=\ln (\nabla E U) \mid y=\text { lottery }\right)+\ln (1-\nabla E U \mid y=\text { riskless })
$$

We assume that errors are normally distributed, but we relax the assumption that the residuals from the same subjects are uncorrelated (i.e., we allow correlation between the decision rows within the same subject), as there are nine observations from each subject. Parameters $r_{0}$ and $r_{1}$ are estimated using maximum likelihood and standard errors are clustered at the subject-level.

\subsection{Table 4: Structural Estimation by the Least Squares}

For structural estimation of parameters in Column (1) of Table 4, we adopt the nonlinear least squares estimation following Andreoni and Sprenger (2012). Following Laibson (1997) we assume that the preferences can be represented by following time-separable quasi-hyperbolic CRRA utility function.

$$
U\left(x_{t}, x_{t+k} \mid T_{i}\right)=x_{t}^{\alpha\left(T_{i}\right)}+\beta\left(T_{i}\right)^{t_{0}} \delta\left(T_{i}\right)^{k} x_{t+k}^{\alpha\left(T_{i}\right)}
$$

$\alpha=1-r$ is curvature of utility function, where $r$ is the coefficient of relative risk aversion. $t_{0}=1$ if the early payment date is the day of experiment, and zero otherwise. $k$ is the delay length (i.e., the difference between early and later payment dates in number of days). We assume that subjects maximize utility subject to the following intertemporal budget constraint,

$$
x_{t}+\frac{x_{t+k}}{p} \leqq m
$$

where the treatment $T_{i}=1$ if hard-earned money, and $T_{i}=0$ if windfall money. To test the treatment we assume that each parameter has following linear specification. $\beta\left(T_{i}\right)$ is present-bias estimator such that $\beta\left(T_{i}\right)=\beta_{0}+\beta_{1} T_{i} . \delta\left(T_{i}\right)$ is discount factor such that $\delta\left(T_{i}\right)=\delta_{0}+\delta_{1} T_{i}$ and $\alpha\left(T_{i}\right)$ is utility curvature 
such that $\alpha\left(T_{i}\right)=\alpha_{0}+\alpha_{1} T_{i}$. The first order condition for above utility maximization problem is,

$$
p=\frac{x_{t}^{\alpha\left(T_{i}\right)-1}}{\beta\left(T_{i}\right)^{t_{0}} \delta\left(T_{i}\right)^{k} x_{t+k}^{\alpha\left(T_{i}\right)-1}}
$$

Replacing $x_{t}$ and rearranging (10), we can derive following non-linear regression equation, where the dependent variable is the allocation to the later date, $x_{t+k}$. We assume that each subject $j$ makes $i=1$, $2, \ldots, 36$ allocation decisions.

$$
x_{t+k_{i j}}=\frac{m}{\left[p \beta\left(T_{i}\right)^{t_{0}} \delta\left(T_{i}\right)^{k}\right]^{\frac{1}{\alpha\left(T_{i}\right)-1}}+\frac{1}{p}}+\epsilon_{i j}
$$

We assume that errors are normally distributed, but but we relax the assumption that the residuals from the same subjects are uncorrelated, i.e., $E\left[e_{h j} e_{i j}\right] \neq 0$ for decisions $h \neq i$ within the same subject $j$. The parameters $\beta, \delta$, and $\alpha$ are estimated using least squares and the standard errors are clustered at the subject-level.

\subsection{Table 4: Structural Estimation from Two-limit Tobit}

In the data, we observe a large fraction of corner solutions. To address potential concerns over a large fraction of corner solutions (Wooldridge, 2002), in Column (3) of Table 4, we used Two-limit Tobit model as an alternative estimation strategy following Andreoni and Sprenger (2012). We assume that each subject $j$ makes $i=1,2, \ldots, 36$ allocation decisions according to the following log-linear model, derived from the first order condition (10). ${ }^{34}$

$$
\ln \left(\frac{x_{t}}{x_{t+k}}\right)_{i j}=\frac{\ln \beta}{\alpha-1} \cdot t_{0}+\frac{\ln \delta}{\alpha-1} \cdot k+\frac{1}{\alpha-1} \cdot \ln (P)+\epsilon_{i j}
$$

To test treatment effect on $\beta, \delta$, and $\alpha$, we add three interaction variables, $t_{0} \times T_{i}, k \times T_{i}$, and $\ln P \times T_{i}$, respectively, where the treatment $T_{i}=1$ if hard-earned money, and $T_{i}=0$ for windfall money. We assume that parameter $\beta\left(T_{i}\right), \delta\left(T_{i}\right)$, and $\alpha\left(T_{i}\right)$ has linear specification as in subsection 5.2.

$$
\ln \left(\frac{x_{t}}{x_{t+k}}\right)_{i j}=\theta_{1} \cdot t_{0}+\theta_{2} \cdot k+\theta_{3} \cdot \ln P+\theta_{4} \cdot\left(t_{0} \times T_{i}\right)+\theta_{5} \cdot\left(k \times T_{i}\right)+\theta_{6} \cdot\left(\ln P \times T_{i}\right)+\epsilon_{i j}
$$

The dependent variable, i.e., the log-ratio of intertemporal allocation between $t$, and $t+k$, is bounded by $\ln \left(\frac{x_{t}=0}{x_{t+k}}\right)$ and $\ln \left(\frac{x_{t}}{x_{t+k}=0}\right)$ and therefore, parameters $\theta_{k}$ can be estimated from the two-limit Tobit

\footnotetext{
${ }^{34}$ See also Andreoni and Sprenger (2012), pp. 3342, for derivation of the log-linear model.
} 
regression. Again, we assume that errors are normally distributed, but but we relax the assumption that the residuals from the same subjects are uncorrelated, i.e., $E\left[e_{h j} e_{i j}\right] \neq 0$ for decisions $h \neq i$ within the same subject $j$. The standard errors are clustered at the subject level. For the windfall group, we can evaluate the present-bias parameter, $\beta_{\text {windfall }}$, as $\beta_{\text {windfall }}=\exp \left(\frac{\theta_{1}}{\theta_{3}}\right)$, discount factor, $\delta_{\text {windfall }}$, as $\delta_{\text {windfall }}=\exp \left(\frac{\theta_{2}}{\theta_{3}}\right)$, and curvature, $\alpha_{\text {windfall }}$, as $\alpha_{\text {windfall }}=\frac{1}{\theta_{3}}+1$, respectively. Likewise, for the hard-earned group, present-bias parameter, $\beta_{\text {earned }}$, discount factor, $\delta_{\text {earned }}$, and curvature, $\alpha_{\text {earned }}$ can be evaluated as, $\beta_{\text {earned }}=\exp \left(\frac{\theta_{1}+\theta_{4}}{\theta_{3}+\theta_{6}}\right), \delta_{\text {earned }}=\exp \left(\frac{\theta_{2}+\theta_{5}}{\theta_{3}+\theta_{6}}\right)$, and $\alpha_{\text {earned }}=\frac{1}{\theta_{3}+\theta_{6}}+1$, respectively.

\section{References}

Andersen, S., G. W. Harrison, M. I. Lau, E. E. Rutstrom. 2008. Eliciting risk and time preferences. Econometrica. 76(3) 583-618.

Andersen, S., G. W. Harrison, M. I. Lau, E. E. Rutstrom. 2014. Discounting behavior : A reconsideration. European Economic Review. 71 15-3.

Andersen, S., J. Y. Campbell, K. M. Nielsen, T. Ramadorai. 2015. Inattention and inertia in household finance: evidence from the Danish mortgage market. NBER working paper 21386.

Anderson, L. R., J. M. Mellor. 2008. Predicting health behaviors with an experimental measure of risk preference. Journal of Health Economics. 27(5) 1260-1274.

Andren, N., H. Jankensgard. 2015. Wall of cash: The investment-cash flow sensitivity when capital becomes abundant. Journal of Banking \& Finance. 50 204-213.

Andreoni, J., M. A. Kuhn, C. Sprenger. 2013. On measuring time preferences. NBER Working Paper No. 19392.

Andreoni, J., C. Sprenger. 2012. Estimating time preferences from convex budgets. American Economic Review. 102(7) 3333-3356.

Augenblick N., S. Nicholson. 2015. Ballot position, choice fatigue, and voter behavior. Review of Economic Studies. Under review.

Barber, B. M., T. Odean. 2000. Trading is hazardous to your wealth: The common stock investment performance of individual investors. Journal of Finance. 55(2) 773-806.

Barber, B. M., T. Odean. 2001. Boys will be boys: Gender, overconfidence, and common stock investment. Quarterly Journal of Economics. 116(1) 261-292.

Barberis, N., M. Huang. 2001. Mental accounting, loss aversion, and individual stock returns. Journal of Finance. 56(4) 1292-1295.

Barsky, R.B., K. Miles, F. T. Juster, M. Shapiro. 1997. Preference parameters and behavioral hetero- 
geneity: an experimental approach in the health and retirement study. Quarterly Journal of Economics. 112(2) 537-579.

Beatty, T., L. Blow, T. Crossley, C. O’Dea. 2011. Cash by any other name? Evidence on labelling from the UK winter fuel payment. IFS Working Papers.

Becker, G. 1996. Accounting for tastes. Cambridge: Harvard University Press.

Camerer, C., G. Loewenstein, M. Rabin. 2004. Advances in behavioural economics. Princeton University Press. Princeton.

Cappelen, A.W., Erik Ø. Sørensen, B. Tungodden. 2010. Responsibility for what? Fairness and individual responsibility. European Economic Review. 54 429-441.

Cárdenas, J .C., N. De Roux, C. R. Jaramillo, L. R. Martinez. 2014. Is it my money or not? An experiment on risk aversion and the house-money effect. Experimental Economics. 17(1) 47-60.

Chabris, C. F., D. Liabson, C. L. Morris, J. P. Schuldt, D. Taubinsky. 2008. Individual laboratorymeasured discount rates predict field behavior. Journal of Risk and Uncertainty. 37(2-3) 237-269.

Cherry, T. L., P. Frykblom, J. F. Shogren. 2002. Hardnose the dictator. American Economic Review. 92(4) 1218-1221.

Cherry, T. L., S. Kroll, J. F. Shogren. 2005. The impact of endowment heterogeneity and origin on public good contributions: evidence from the lab. Journal of Economic Behavior and Organization. 57(3) 357-365.

Coller, M., M. B. Williams. 1999. Eliciting individual discount rates. Experimental Economics. 2(2) 107-127.

Corgnet, B., R. Hernan-Gonzalez, P. Kujal, D. Porter. 2014. The effect of earned versus house money on price bubble formation in experimental asset markets. Review of Finance. 18(5) 1-34.

Croson, R., U. Gneezy. 2009. Gender differences in preferences. Journal of Economic Literature. 47(2) 1-27.

Danziger, S., J. Levav. L. Avnaim-Pesso. 2011. Extraneous factors in judicial decisions. Proceedings of the National Academy of Sciences. 108(17) 6889-6892.

Dohmen, T., A. Falk, D. Huffman, U. Sunde. 2011. Are risk aversion and impatience related to cognitive ability? American Economic Review. 100(3) 1238-60.

Dohmen, T., A. Falk, D. Huffman, U. Sunde. 2012. Interpreting time horizon effects in intertemporal choice. IZA Discussion Paper No. 6385.

Dohmen, T., A. Falk, D. Huffman, U. Sunde, J. Schupp, G. G. Wagner. 2005. Individual risk attitudes: New evidence from a large, representative, experimentally-validated survey. IZA Discussion Paper No. 1730. 
Doskeland, Trond.M., Hans. K. Hvide. 2011. Do individual investors have asymmetric information based on work experience? Journal of Finance. 66(3) 1011-1041.

Frederick, S., G. Loewenstein, T. O’Donoghue. 2002. Time discounting and time preference: A critical review. Journal of Economic Literature. 40(2) 351-401.

Friedman, M. A. (1957). A Theory of Consumptiont Function. Princeton University Press.

Guillen, P., R. Veszteg. 2012. On "lab rats". Journal of Socio-Economics. 41(5) 714-720.

Harrison, G. W., E. Rutström. 2008. Risk aversion in the laboratory, In J. Cox \& G. Harrison (Eds.), Research in Experimental Economics: Vol. 12. Risk aversion in experiments (pp. 41-196) Bingley: Emerald.

Heath, C., B. J. Soll. 1996. Mental budgeting and consumer decisions. Journal of Consumer Research. 23(1) 40-52.

Holt, C. A., S. K. Laury. 2002. Risk aversion and incentive effects. American Economic Review. 92(5) 1644-1655.

Hvide, Hans.K., Møen, J. 2010. Lean and hungry or fat and content? Entrepreneurs' wealth and start-up performance. Management Science. 56(8) 1242-1258.

Jacoby, H. 2002. Is there an intrahousehold 'Flypaper effect'? Evidence from a school feeding programme. The Economic Journal. 112(476) 196-221.

Jensen, M.C. 1986. Agency costs of free cash flow, corporate finance, and takeovers. American Economic Review. 76(2) 323-329.

Kagel, J. H. \& D. Levin (1986). The winner's curse and public information in public value auctions. American Economic Review, 76(5) 894-920.

Kahneman, D., A. Tversky. 1979. Prospect theory: An analysis of decision under risk. Econometrica. 47(2) 263-291.

Kaplan, S. N., B. A. Minton. 2011. How has CEO turnover changed?. International Review of Finance. 12(1) 57-87.

Knetsch, Jack L. 1989. The endowment effect and evidence of nonreversible indifference curves. American Economic Review. 79(5) 1277-1284.

Kooreman, P. 2000. The labeling effect of a child benefit system. American Economic Review. 90(3) $571-583$.

Kuhn, M., P. Kuhn, M. C. Villeval. 2014. Self control and intertemporal choice: Evidence from glucose and depletion interventions. CESifo Working Paper Series No. 4609.

Laibson, D. 1997. Golden eggs and hyperbolic discounting. Quarterly Journal of Economics. 112 443-477. 
Lee, J. H. (2015). Source of income effect on individual risk- and time-preferences: Experimental approach. Unpublished doctoral dissertation, University of Aberdeen.

Morrison, W. G., R. J. Oxoby. 2013. The endowment effect and intertemporal choice: a laboratory investigation. Canadian Journal of Economics. 46(2) 689-704.

Odean, T. 1998. Are investors reluctant to realize their losses? Journal of Finance. 53(5) 1775-1798.

Odean, T. 1999. Do investors trade too much? American Economic Review. 89(5) 1279-1298.

Plott, C. 1996. Rational individual behavior in markets and social choice processes: The discovered preference hypothesis. In: The rational foundations of eeconomic behavior. London: Macmillan. pp. 225-50.

Souleles, N. S. 1999. The response of household consumption to income tax refunds. American Economic Review. 89(4) 947 - 958.

Souleles, N. S. 2002. Consumer response to the Reagan tax cuts. Journal of Public Economics. 85(1) $99-120$.

Spraggon, J., R. J. Oxoby. 2009. An experimental investigation of endowment source heterogeneity in two-person public good games. Economics Letters. 104(2) 102-105.

Stein, J. C. 1988. Takeover threats and managerial myopia. Journal of Political Economy. 96(1) $61-80$.

Stein, J. C. 1989. Efficient capital markets, inefficient firms: A model of myopic corporate behavior. Quarterly Journal of Economics. 104(4) 655-669.

Thaler, R. 1999. Mental accounting matters. Journal of Behavioral Decision Making. 12 183-206.

Thaler, R. 2008. Mental accounting and consumer choice. Marketing Science. 27(1) 15-25.

Thaler, R., E. Johnson. 1990. Gambling with the house money and trying to break even: the effects of prior outcomes on risky choice. Management Science. 36(6) 646-660.

Wooldridge, J. M. 2002. Econometric Analysis of Cross Section and Panel Data. Cambridge, MA: MIT Press. 


\section{Table 1. OLS (Risk-Preferences)}

The table reports the relationship between self-reported measures of risk willingness, and socio demographics and the frequency with which riskless Option A was chosen (i.e., Switching Point) from an OLS. The table reports coefficient and standard errors in brackets. The dependent variable is the frequency with which riskless Option A was chosen. The higher the frequency, the greater the risk-aversion. Earned is a dummy

\begin{tabular}{|c|c|c|c|c|c|c|c|}
\hline VARIABLES & $\begin{array}{c}(1) \\
\text { Model } \\
\end{array}$ & $\begin{array}{c}(2) \\
\text { Model } \\
\end{array}$ & $\begin{array}{c}(3) \\
\text { Model } \\
\end{array}$ & $\begin{array}{c}(4) \\
\text { Model } \\
\end{array}$ & $\begin{array}{c}(5) \\
\text { Model } \\
\end{array}$ & $\begin{array}{c}(6) \\
\text { Model } \\
\end{array}$ & $\begin{array}{c}(7) \\
\text { Model }\end{array}$ \\
\hline Earned & $\begin{array}{c}1.636^{* * * *} \\
(0.268)\end{array}$ & $\begin{array}{c}1.557 * * * \\
(0.268)\end{array}$ & $\begin{array}{c}1.555^{* * *} * \\
(0.273)\end{array}$ & $\begin{array}{c}1.545^{* * * *} \\
(0.276)\end{array}$ & $\begin{array}{c}1.548 * * * \\
(0.290)\end{array}$ & $\begin{array}{c}1.664 * * * \\
(0.302)\end{array}$ & $\begin{array}{c}1.615^{* * * *} \\
(0.305)\end{array}$ \\
\hline Smoking & & $\begin{array}{l}-0.620 \\
(0.419)\end{array}$ & $\begin{array}{c}-0.518 \\
(0.438)\end{array}$ & $\begin{array}{c}-0.481 \\
(0.439)\end{array}$ & $\begin{array}{l}-0.506 \\
(0.451)\end{array}$ & $\begin{array}{l}-0.374 \\
(0.502)\end{array}$ & $\begin{array}{l}-0.286 \\
(0.504)\end{array}$ \\
\hline Exercise & & $\begin{array}{c}-0.461^{*} \\
(0.268)\end{array}$ & $\begin{array}{c}-0.416 \\
(0.276)\end{array}$ & $\begin{array}{l}-0.362 \\
(0.280)\end{array}$ & $\begin{array}{l}-0.338 \\
(0.298)\end{array}$ & $\begin{array}{l}-0.295 \\
(0.318)\end{array}$ & $\begin{array}{l}-0.197 \\
(0.319)\end{array}$ \\
\hline Contraception & & & $\begin{array}{l}-0.138 \\
(0.159)\end{array}$ & $\begin{array}{l}-0.115 \\
(0.161)\end{array}$ & $\begin{array}{l}-0.124 \\
(0.173)\end{array}$ & $\begin{array}{l}-0.173 \\
(0.181)\end{array}$ & $\begin{array}{l}-0.146 \\
(0.178)\end{array}$ \\
\hline Drinking & & & $\begin{array}{l}0.0204 \\
(0.277)\end{array}$ & $\begin{array}{l}0.0734 \\
(0.284)\end{array}$ & $\begin{array}{l}0.0163 \\
(0.299)\end{array}$ & $\begin{array}{c}0.103 \\
(0.312)\end{array}$ & $\begin{array}{l}-0.0329 \\
(0.327)\end{array}$ \\
\hline Risk-taking & & & & $\begin{array}{l}-0.166 \\
(0.192)\end{array}$ & $\begin{array}{l}-0.253 \\
(0.210)\end{array}$ & $\begin{array}{l}-0.311 \\
(0.219)\end{array}$ & $\begin{array}{l}-0.368^{*} \\
(0.217)\end{array}$ \\
\hline Trust & & & & $\begin{array}{l}-0.231 \\
(0.198)\end{array}$ & $\begin{array}{l}-0.270 \\
(0.208)\end{array}$ & $\begin{array}{l}-0.326 \\
(0.222)\end{array}$ & $\begin{array}{l}-0.401^{*} \\
(0.219)\end{array}$ \\
\hline Savings A/C & & & & & $\begin{array}{l}0.0268 \\
(0.325)\end{array}$ & $\begin{array}{l}-0.180 \\
(0.352)\end{array}$ & $\begin{array}{l}-0.125 \\
(0.349)\end{array}$ \\
\hline Regular savers & & & & & $\begin{array}{r}-0.0182 \\
(0.390)\end{array}$ & $\begin{array}{c}0.128 \\
(0.414)\end{array}$ & $\begin{array}{c}0.118 \\
(0.400)\end{array}$ \\
\hline Lending & & & & & $\begin{array}{l}-0.121 \\
(0.284)\end{array}$ & $\begin{array}{l}-0.0870 \\
(0.303)\end{array}$ & $\begin{array}{l}-0.0746 \\
(0.299)\end{array}$ \\
\hline Plagiarism & & & & & $\begin{array}{l}-0.165 \\
(0.316)\end{array}$ & $\begin{array}{l}-0.184 \\
(0.341)\end{array}$ & $\begin{array}{l}-0.241 \\
(0.335)\end{array}$ \\
\hline Cheating & & & & & $\begin{array}{c}0.287 \\
(0.463)\end{array}$ & $\begin{array}{c}0.329 \\
(0.503)\end{array}$ & $\begin{array}{c}0.364 \\
(0.498)\end{array}$ \\
\hline Postpone & & & & & $\begin{array}{c}0.492 \\
(0.317)\end{array}$ & $\begin{array}{c}0.561 \\
(0.343)\end{array}$ & $\begin{array}{l}0.556^{*} \\
(0.332)\end{array}$ \\
\hline Age & & & & & & $\begin{array}{c}0.470 \\
(0.326)\end{array}$ & $\begin{array}{c}0.352 \\
(0.321)\end{array}$ \\
\hline Year & & & & & & $\begin{array}{l}-0.267 \\
(0.215)\end{array}$ & $\begin{array}{l}-0.180 \\
(0.213)\end{array}$ \\
\hline Gender & & & & & & $\begin{array}{l}-0.587 \\
(0.363)\end{array}$ & $\begin{array}{l}-0.584 \\
(0.361)\end{array}$ \\
\hline Course & & & & & & $\begin{array}{c}0.194 \\
(0.335)\end{array}$ & $\begin{array}{l}-0.0500 \\
(0.338)\end{array}$ \\
\hline Employment & & & & & & $\begin{array}{l}-0.0239 \\
(0.512)\end{array}$ & $\begin{array}{l}0.0574 \\
(0.513)\end{array}$ \\
\hline Daily spending & & & & & & $\begin{array}{c}0.112 \\
(0.352)\end{array}$ & $\begin{array}{c}0.220 \\
(0.346)\end{array}$ \\
\hline Others & & & & & & & $\begin{array}{c}0.409 \\
(0.346)\end{array}$ \\
\hline Experience & & & & & & & $\begin{array}{l}-0.393 \\
(0.336)\end{array}$ \\
\hline Confidence & & & & & & & $\begin{array}{c}-1.040^{*} \\
(0.553)\end{array}$ \\
\hline Constant & $\begin{array}{c}4.075^{* * *} * \\
(0.187)\end{array}$ & $\begin{array}{c}4.368 * * * \\
(0.224)\end{array}$ & $\begin{array}{c}4.601 * * * \\
(0.405)\end{array}$ & $\begin{array}{c}5.099 * * * \\
(0.529)\end{array}$ & $\begin{array}{c}5.076 * * * \\
(0.609)\end{array}$ & $\begin{array}{c}5.266 * * * \\
(0.735)\end{array}$ & $\begin{array}{c}5.610 * * * \\
(0.820)\end{array}$ \\
\hline $\begin{array}{c}N \\
\text { Adjusted R-squared }\end{array}$ & $\begin{array}{c}78 \\
0.320\end{array}$ & $\begin{array}{c}78 \\
0.348\end{array}$ & $\begin{array}{c}78 \\
0.337\end{array}$ & $\begin{array}{c}78 \\
0.338\end{array}$ & $\begin{array}{c}78 \\
0.314\end{array}$ & $\begin{array}{c}78 \\
0.299\end{array}$ & $\begin{array}{c}78 \\
0.347\end{array}$ \\
\hline
\end{tabular}


is a dummy variable that takes on a value of one for a participant is in the hard-earned group. Smoking, Exercise, Drinking, Savings A/C, Regular savers, Lending, Plagiarism, Cheating, and Postpone are behavioural dummy variables that take on a value of one if a participant is a smoker, exercise regularly, drinks at least once a week, has a savings a/c, is a regular saver, often lends money to others, plagiarised university course work at least once, has cheated on a university exam at least once, and often postpone duties, respectively. Contraception, Risk-taking, and Trust are the self-reported categorical variable that each takes a value from 1 to 3, depending on general degree of each variable. Age, Year (number of years in university), Gender, Course, Employment, and Daily spending are socio demographic variables. Age has three categories; older (i.e., age $>24$ ), middle (i.e., $22 \leq$ age $\leq 24$ ), and younger (i.e., age $<22$ ). Year (number of years in university) is measured in number of years. Daily spending is the binary variable that takes a value of one if subject's average daily spending (converted to \$) is in upper quartile. Gender, Course, and Employment is a dummy variable that takes on a value of one if a participant is male, is in business school course of degrees, and has an employment history more than one year, respectively. Others, Experience, and Confidence control for some (possible) experimental noises. Others is a dummy variable that takes on a value of one if a participant knew other participants in the previous or same session. Experience is a dummy variable that takes on a value of one if a participant has an experience in participating experiment. Confidence is a dummy variable that takes on a value of one if a participant was not confident in receiving payments as in the instructions. Asterisks next to the coefficients are levels of significance of the estimates, denoting $*=\mathrm{p}<0.10, * *=\mathrm{p}<0.05$, and $* * *=\mathrm{p}<0.01$. 


\section{Table 2. Structural estimation of the CRRA coefficient}

The table reports the structural estimation of the CRRA coefficient $r$ for each group from Luce's (1959) choice probabilistic formulation, where parameter $\eta$ estimates the stochastic noise from the perspective of the expected utility maximisation. The standard errors are in brackets and are clustered at an individual level. The table also reports the difference between the two groups and the asterisks next to the brackets are levels of significance, denoting $*=p<0.10, * *=p<0.05$, and $* * *=p<0.01$. Column (1) reports the estimation from a full sample. Column (2) reports the estimation excluding 7 subjects who said in the survey that they were not confident they would receive payments. Column (3) reports the estimation excluding 32 subjects who knew other participants in the previous or same session. Column (4) reports the estimation excluding 39 subjects who have participated in economics experiments before.

\begin{tabular}{ccccc}
\hline \hline & $(1)$ & $(2)$ & $(3)$ & $(4)$ \\
& Model & Model & Model & Model \\
\hline \multirow{2}{*}{ CRRA curvature $: \boldsymbol{r}$} & & & & \\
Endowed & 0.021 & 0.054 & -0.109 & -0.001 \\
& $(0.05)$ & $(0.06)$ & $(0.07)$ & $(0.07)$ \\
Earned & 0.447 & 0.461 & 0.438 & 0.483 \\
& $(0.05)$ & $(0.05)$ & $(0.07)$ & $(0.094)$ \\
Difference & 0.427 & 0.407 & 0.547 & 0.484 \\
& $(0.08)^{* * * *}$ & $(0.08)^{* * *}$ & $(0.10)^{* * *}$ & $(0.12)^{* * *}$ \\
& & & & \\
noise parameter : $\boldsymbol{\eta}$ & 0.11 & 0.11 & 0.11 & 0.12 \\
& $(0.01)^{* * * *}$ & $(0.01)^{* * *}$ & $(0.01)^{* * *}$ & $(0.02)^{* * *}$ \\
& & & & \\
Observation & 702 & 639 & 414 & 351 \\
Log-likelihood & -163.48 & -149.90 & -96.54 & -87.10 \\
\hline
\end{tabular}




\section{Table 3. OLS (Time-Preferences)}

The table reports the relationship between self-reported time-preferences measures and the allocation to the later date from an OLS. More patient subjects would make more allocation to the later date. The table reports coefficient and standard errors in brackets. The standard errors are clustered at an individual level. Earned is a dummy variable that takes on a value of one for a subject in the hard-earned group. Smoking, Exercise, and Track are the self-reported measure of behaviour that is related to the individual time-preferences (e.g., Chabris et al., 2008). These are dummy variables that each takes on a value of one if individual is a smoker, exercises regularly, and keep records of expenses, respectively.

\begin{tabular}{|c|c|c|c|c|c|c|}
\hline VARIABLES & $\begin{array}{c}(1) \\
\text { Model } \\
\end{array}$ & $\begin{array}{c}(2) \\
\text { Model } \\
\end{array}$ & $\begin{array}{c}(3) \\
\text { Model } \\
\end{array}$ & $\begin{array}{c}(4) \\
\text { Model } \\
\end{array}$ & $\begin{array}{c}(5) \\
\text { Model } \\
\end{array}$ & $\begin{array}{c}(6) \\
\text { Model } \\
\end{array}$ \\
\hline Earned & $\begin{array}{c}2.441 * * \\
(0.920)\end{array}$ & $\begin{array}{c}2.171^{* *} \\
(0.923)\end{array}$ & $\begin{array}{c}2.354 * * * \\
(0.838)\end{array}$ & $\begin{array}{c}2.292 * * * \\
(0.816)\end{array}$ & $\begin{array}{c}2.509 * * * \\
(0.727)\end{array}$ & $\begin{array}{c}2.509 * * \\
(0.962)\end{array}$ \\
\hline Smoking & & $\begin{array}{l}-1.457 \\
(1.238)\end{array}$ & $\begin{array}{l}-1.046 \\
(1.275)\end{array}$ & $\begin{array}{l}-0.909 \\
(1.103)\end{array}$ & $\begin{array}{l}-0.150 \\
(1.218)\end{array}$ & $\begin{array}{l}-0.150 \\
(1.467)\end{array}$ \\
\hline Exercise & & $\begin{array}{l}-0.539 \\
(0.932)\end{array}$ & $\begin{array}{l}-0.836 \\
(1.029)\end{array}$ & $\begin{array}{l}-1.294 \\
(0.963)\end{array}$ & $\begin{array}{l}-1.020 \\
(0.966)\end{array}$ & $\begin{array}{l}-1.020 \\
(1.174)\end{array}$ \\
\hline Track & & $\begin{array}{l}-0.124 \\
(0.909)\end{array}$ & $\begin{array}{l}-0.395 \\
(1.031)\end{array}$ & $\begin{array}{l}-0.0906 \\
(1.072)\end{array}$ & $\begin{array}{c}0.760 \\
(1.042)\end{array}$ & $\begin{array}{c}0.760 \\
(1.131)\end{array}$ \\
\hline Risk-taking & & & $\begin{array}{c}-1.111 * * \\
(0.505)\end{array}$ & $\begin{array}{c}-1.530 * * \\
(0.642)\end{array}$ & $\begin{array}{l}-0.660 \\
(0.543)\end{array}$ & $\begin{array}{l}-0.660 \\
(0.837)\end{array}$ \\
\hline Patience & & & $\begin{array}{l}-0.545 \\
(0.705)\end{array}$ & $\begin{array}{l}-0.526 \\
(0.679)\end{array}$ & $\begin{array}{l}-0.442 \\
(0.613)\end{array}$ & $\begin{array}{l}-0.442 \\
(0.719)\end{array}$ \\
\hline Temptation & & & $\begin{array}{c}0.205 \\
(0.638)\end{array}$ & $\begin{array}{c}0.128 \\
(0.572)\end{array}$ & $\begin{array}{c}0.216 \\
(0.554)\end{array}$ & $\begin{array}{c}0.216 \\
(0.671)\end{array}$ \\
\hline Trust & & & $\begin{array}{l}0.0150 \\
(0.723)\end{array}$ & $\begin{array}{l}0.0455 \\
(0.621)\end{array}$ & $\begin{array}{l}-0.691 \\
(0.548)\end{array}$ & $\begin{array}{c}-0.691 \\
(0.734)\end{array}$ \\
\hline Present-bias & & & $\begin{array}{c}1.476 \\
(1.347)\end{array}$ & $\begin{array}{c}1.495 \\
(1.292)\end{array}$ & $\begin{array}{l}-0.0117 \\
(1.303)\end{array}$ & $\begin{array}{l}-0.0117 \\
(1.473)\end{array}$ \\
\hline Age & & & & $\begin{array}{l}-2.067 \\
(1.303)\end{array}$ & $\begin{array}{l}-1.214 \\
(1.163)\end{array}$ & $\begin{array}{c}-1.214 \\
(1.516)\end{array}$ \\
\hline Year & & & & $\begin{array}{l}1.015 \\
(0.662)\end{array}$ & $\begin{array}{c}0.482 \\
(0.621)\end{array}$ & $\begin{array}{c}0.482 \\
(0.705)\end{array}$ \\
\hline Gender & & & & $\begin{array}{l}-1.268 \\
(0.945)\end{array}$ & $\begin{array}{l}-1.129 \\
(0.790)\end{array}$ & $\begin{array}{l}-1.129 \\
(1.035)\end{array}$ \\
\hline Employment & & & & $\begin{array}{l}-1.360 \\
(1.451)\end{array}$ & $\begin{array}{l}-1.393 \\
(1.693)\end{array}$ & $\begin{array}{l}-1.393 \\
(1.733)\end{array}$ \\
\hline Daily spending & & & & $\begin{array}{l}-0.0357 \\
(1.201)\end{array}$ & $\begin{array}{l}-0.559 \\
(1.065)\end{array}$ & $\begin{array}{c}-0.559 \\
(1.147)\end{array}$ \\
\hline Course & & & & $\begin{array}{c}0.451 \\
(0.997)\end{array}$ & $\begin{array}{c}0.985 \\
(0.985)\end{array}$ & $\begin{array}{c}0.985 \\
(1.134)\end{array}$ \\
\hline Nationality & & & & $\begin{array}{l}-0.0163 \\
(1.101)\end{array}$ & $\begin{array}{l}-0.295 \\
(0.995)\end{array}$ & $\begin{array}{l}-0.295 \\
(1.226)\end{array}$ \\
\hline Others & & & & & $\begin{array}{l}-1.853^{*} \\
(1.023)\end{array}$ & $\begin{array}{c}-1.853 \\
(1.298)\end{array}$ \\
\hline Reason & & & & & $\begin{array}{c}-3.674 * * * \\
(1.119)\end{array}$ & $\begin{array}{c}-3.674 * * * \\
(1.356)\end{array}$ \\
\hline Price ratio & & $\begin{array}{c}19.44 * * * \\
(0.994)\end{array}$ & $\begin{array}{c}19.44 * * * \\
(0.995)\end{array}$ & $\begin{array}{c}19.44 * * * \\
(0.997)\end{array}$ & $\begin{array}{c}19.44 * * * \\
(0.997)\end{array}$ & \\
\hline Constant & $\begin{array}{c}7.789 * * * \\
(0.668)\end{array}$ & $\begin{array}{c}-18.23 * * * \\
(1.735)\end{array}$ & $\begin{array}{c}-15.11^{* * *} \\
(3.400)\end{array}$ & $\begin{array}{c}-14.83^{* * * *} \\
(3.118)\end{array}$ & $\begin{array}{c}-14.44 * * * \\
(3.000)\end{array}$ & $\begin{array}{c}12.34 * * * \\
(2.967)\end{array}$ \\
\hline Observations & 2,124 & 2,124 & 2,124 & 2,124 & 2,124 & 59 \\
\hline Adjusted R-squared & 0.033 & 0.438 & 0.457 & 0.480 & 0.521 & 0.148 \\
\hline
\end{tabular}

Risk-taking, Patience, Temptation, and Trust are the self-reported variables that each take a value from 1 to 3 depending on the level of risk-taking, patience, resisting temptation, and trusting people in general, respectively. Present-Bias is a dummy variable that takes a value of one if subjects were present-biased in the hypothetical question. Age, Year (number of years in university), Gender, Employment, Daily spending, Course, and Nationality are socio demographic variables. Age has two categories; older (i.e., age $\geq 21$ ), and younger (i.e., age $<21$ ). Year (number of years in university) is measured in number of years. Daily spending is the binary variable that takes a value of one if subject's average daily 
spending (measured in $£$ ) is in upper quartile. Gender, Employment, Course, and Nationality is a dummy variable that takes on a value of one if a participant is male, has an employment history more than one year, is in business school course of degrees, and is a resident of UK \& Ireland, respectively. Others and Reason controls for some possible experimental noises. Others is a dummy variable that takes on a value of one if a participant knew other participants in the previous or same session. Reason is a dummy variable that takes on a value of one if a participant has some specific reasons for their choices other than the monetary rewards. Price ratio is the relative price of the later date allocation. Asterisks next to the coefficients are levels of significance of the estimates, denoting $*=p<0.10, * *=p<0.05$, and $* * *=p<0.01$. In Column (6), we collect one number from each individual, their mean allocation to the later date and reports regression results of this. 


\section{Table 4. Parameter estimation: Non-Linear Squares (NLS)}

The table reports the estimated parameters from NLS. Standard errors are in brackets and are clustered on an individual level. Coefficient $\alpha=1-\theta$ is the curvature of the utility function, where $\theta$ is the CRRA coefficient. $\beta$ is the present-bias estimator, where $\beta<1$ is an indication of present-bias. Lastly, $\delta$ is the discounting factor and $r=\left(1 / \delta^{365}\right)-1$ is the annual discounting rate. Column (1) and Column (2) reports estimations from the NLS. Column (1) reports estimations from the full sample of 59 subjects. Column (2) reports the results when participation fee of $£ 1.50$ was added to each time period. Column (3) reports the estimation from two-limit Tobit model. Column (4) displays the results in Andreoni and Sprenger (2012) and Column (5) displays the results in Andreoni et al. (2013), respectively. The "Difference" reports the difference in the estimates between the two groups and asterisks next to the brackets are levels of significance, denoting $*=p<0.10, * *=p<0.05$, and $* * *=p<$ 0.01 .

\begin{tabular}{|c|c|c|c|c|c|}
\hline Method: & $\begin{array}{c}\text { NLS } \\
\text { (1) }\end{array}$ & $\begin{array}{c}\text { NLS } \\
\text { (2) }\end{array}$ & $\begin{array}{l}\text { Tobit } \\
\text { (3) }\end{array}$ & $\begin{array}{c}\text { AS (2012) } \\
\text { (4) }\end{array}$ & $\begin{array}{c}\text { AKS (2013) } \\
(5)\end{array}$ \\
\hline \multicolumn{6}{|c|}{ Annual Disc. Rate } \\
\hline Endowed & $\begin{array}{c}1.242 \\
(0.225)\end{array}$ & $\begin{array}{c}1.201 \\
(0.222)\end{array}$ & $\begin{array}{c}1.652 \\
(0.333)\end{array}$ & $\begin{array}{r}0.371 \\
(0.091)\end{array}$ & $\begin{array}{c}0.679 \\
(0.148)\end{array}$ \\
\hline Earned & $\begin{array}{c}0.387 \\
(0.143)\end{array}$ & $\begin{array}{c}0.384 \\
(0.152)\end{array}$ & $\begin{array}{c}0.594 \\
(0.181)\end{array}$ & & \\
\hline Difference & $\begin{array}{c}-0.855 \\
(0.267)^{* * *}\end{array}$ & $\begin{array}{c}-0.816 \\
(0.267)^{* * *}\end{array}$ & $\begin{array}{c}-1.058 \\
(0.379)^{* * *}\end{array}$ & & \\
\hline \multicolumn{6}{|c|}{ Present bias: $\beta$} \\
\hline Endowed & $\begin{array}{c}0.938 \\
(0.019)\end{array}$ & $\begin{array}{c}0.940 \\
(0.019)\end{array}$ & $\begin{array}{c}0.922 \\
(0.021)\end{array}$ & $\begin{array}{c}1.007 \\
(0.006)\end{array}$ & $\begin{array}{c}0.988 \\
(0.009)\end{array}$ \\
\hline Earned & $\begin{array}{c}0.933 \\
(0.027)\end{array}$ & $\begin{array}{c}0.942 \\
(0.027)\end{array}$ & $\begin{array}{c}0.939 \\
(0.030)\end{array}$ & & \\
\hline Difference & $\begin{array}{l}-0.005 \\
(0.034)\end{array}$ & $\begin{array}{c}0.002 \\
(0.033)\end{array}$ & $\begin{array}{c}0.017 \\
(0.036)\end{array}$ & & \\
\hline
\end{tabular}

\section{CRRA curvature: $\alpha$}

\begin{tabular}{cccccc} 
Endowed & 0.861 & 0.809 & 0.988 & 0.897 & 0.928 \\
& $(0.183)$ & $(0.020)$ & $(0.002)$ & $(0.009)$ & $(0.007)$ \\
Earned & 0.866 & 0.802 & 0.989 & & \\
& $(0.019)$ & $(0.019)$ & $(0.002)$ & & \\
Difference & 0.004 & -0.007 & 0.001 & & \\
& $(0.027)$ & $(0.028)$ & $(0.002)$ & & \\
& & & & & \\
& & & & & \\
R-Sqr / LL & 0.7988 & 0.7978 & -2791.78 & 0.4871 & 0.5910 \\
Observations & 2124 & 2124 & 2124 & 4365 & 1392 \\
Uncensored & - & - & 386 & - & - \\
Clusters & 59 & 59 & 59 & 97 & 58 \\
\hline
\end{tabular}




\section{Table 5. Survey}

The table summarizes the results in the two separate surveys. The first survey (Panel A) was run on the experimental subjects after completing the experiment. The second survey (Panel B) was run online, on 1000 adults from Norway.

\section{Panel A. Experimental Subjects}

\section{Question 1}

\begin{tabular}{cccccc}
\hline \hline & \multicolumn{2}{c}{ Alternatives } & $\mathrm{N}$ & \multicolumn{2}{c}{ Chi - Square test } \\
\cline { 2 - 6 } & (a) Dinner & (b) Top-up & & $\chi$ - square & $\mathrm{p}$-value \\
\hline Earned & $29.5 \%$ & $70.5 \%$ & 78 & 39.3 & $<0.001$ \\
Lottery & & & & & \\
\hline
\end{tabular}

\section{Question 2}

\begin{tabular}{cccccc}
\hline \hline & \multicolumn{2}{c}{ Alternatives } & $\mathrm{N}$ & \multicolumn{2}{c}{ Chi - Square test } \\
\cline { 2 - 6 } & (a) Necessity & (b) Unnecessary & & $\chi$ - square & $\mathrm{p}$-value \\
\hline Earned & $69.2 \%$ & $30.8 \%$ & 78 & 44.0 & $<0.001$ \\
Lottery & & & & & \\
\hline
\end{tabular}

Question 3

\begin{tabular}{ccccc}
\hline \hline & \multicolumn{2}{c}{ Alternatives } & $\mathrm{N}$ & Fischer's Exact test \\
\cline { 2 - 5 } & (a) New phone & (b) Save & & $\mathrm{p}$-value \\
\hline Earned & $2.6 \%$ & $97.4 \%$ & 78 & $<0.001$ \\
Lottery & $33.3 \%$ & & & \\
\hline
\end{tabular}

\section{Question 4}

\begin{tabular}{cccccc}
\hline \hline & \multicolumn{2}{c}{ Alternatives } & $\mathrm{N}$ & \multicolumn{2}{c}{ Chi - Square test } \\
\cline { 2 - 6 } & (a) non refundable & (b) refundable & & $\chi$ - square & $\mathrm{p}$-value \\
\hline Earned & $54.6 \%$ & $45.5 \%$ & 78 & & $<0.001$ \\
& & & & 16.2 & \\
Lottery & $84.4 \%$ & $15.6 \%$ & 78 & & \\
\hline
\end{tabular}

\section{Question 5}

\begin{tabular}{|c|c|c|c|c|}
\hline & Alternatives & $\mathrm{N}$ & \multicolumn{2}{|c|}{$t$ - test } \\
\hline & Average Donation & & $t$ - stat & $\mathrm{p}$-value \\
\hline \multirow[t]{2}{*}{ Earned } & $1540 \mathrm{KRW}(=\$ 15.4)$ & 78 & & \\
\hline & & & 4.03 & $<0.001$ \\
\hline Lottery & $5350 \mathrm{KRW}(=\$ 53.5)$ & 78 & & \\
\hline
\end{tabular}


Panel B. A sample from Norwegian (general) population

\section{Question 1}

\begin{tabular}{cccccc}
\hline \hline & \multicolumn{2}{c}{ Alternatives } & $\mathrm{N}$ & \multicolumn{2}{c}{ Chi - Square test } \\
\cline { 2 - 6 } & (a) Dinner & $\begin{array}{c}\text { (b) Save for } \\
\text { Holidays }\end{array}$ & & $\chi$ - square & $\mathrm{p}-$ value \\
\hline Earned & $18 \%$ & $82 \%$ & 519 & & $<0.01$ \\
Lottery & $48 \%$ & $52 \%$ & 503 & & 104.45 \\
\hline
\end{tabular}

\section{Question 2}

\begin{tabular}{cccccc}
\hline \hline & \multicolumn{2}{c}{ Alternatives } & $\mathrm{N}$ & \multicolumn{2}{c}{ Chi - Square test } \\
\cline { 2 - 6 } & (a) Necessary & (b) Unnecessary & & $\chi$ - square & $\mathrm{p}$-value \\
\hline Earned & $86 \%$ & $14 \%$ & 519 & & $<0.01$ \\
Lottery & $57 \%$ & & & 503 & \\
\hline
\end{tabular}

\section{Question 3}

\begin{tabular}{|c|c|c|c|c|c|}
\hline & \multicolumn{2}{|c|}{ Alternatives } & \multirow[t]{2}{*}{$\mathrm{N}$} & \multicolumn{2}{|c|}{ Chi - Square test } \\
\hline & (a) New phone/Laptop/Tablet & (b) Save & & $\chi$ - square & $\mathrm{p}$-value \\
\hline \multirow[t]{2}{*}{ Earned } & $8 \%$ & $92 \%$ & 519 & & \\
\hline & & & & 0.47 & 0.49 \\
\hline Lottery & $7 \%$ & $93 \%$ & 503 & & \\
\hline
\end{tabular}

\section{Question 4}

\begin{tabular}{cccccc}
\hline \hline & \multicolumn{2}{c}{ Alternatives } & $\mathrm{N}$ & \multicolumn{2}{c}{ Chi - Square test } \\
\cline { 2 - 6 } & (a) non refundable & (b) refundable & & $\chi$ - square & $\mathrm{p}-$ value \\
\hline Earned & $59 \%$ & $41 \%$ & 519 & & $<0.01$ \\
Lottery & $37 \%$ & & & 503 & \\
\hline
\end{tabular}




\section{Table A1. Summary statistics: averages and mean differences}

The table reports averages and mean differences between two groups for the main variables. The table also provides a description for each variable. Panel A present average individual characteristics in the risk-preferences (Holt-Laury) experiment, for: the full sample, the hard-earned money group, and the windfall money group. Likewise, Panel B present average individual characteristics in the time-preferences (Andreoni-Sprenger) experiment, for: the full sample, the hard-earned money group, and the windfall money group. The second-last column reports the mean difference between the hard-earned and windfall money group. The last column reports the t-statistics (or z-statistics) for the mean differences and asterisks denote level of significance $(*=p<0.10, * *=p<0.05$, and $* * *=p<0.01)$.

\section{Panel A: Risk Preferences}

\begin{tabular}{|c|c|c|c|c|c|c|}
\hline Variable & Description & $\begin{array}{c}\text { Full sample } \\
\text { Mean }\end{array}$ & $\begin{array}{c}\text { Hard-earned } \\
\text { Mean }\end{array}$ & $\begin{array}{c}\text { Windfall } \\
\text { Mean }\end{array}$ & Mean Diff & $\mathrm{t}($ or $\mathrm{z})$-stat \\
\hline Age & Subject's age in years & 23.42 & 23.44 & 23.4 & 0.04 & 0.09 \\
\hline Year & University year & 2.86 & 2.95 & 2.78 & 0.17 & 0.65 \\
\hline Gender & $\%$ of male subjects & $56.4 \%$ & $57.9 \%$ & $55.0 \%$ & $2.9 \%$ & 0.26 \\
\hline Course & $\%$ of subjects who are on business school related degree courses & $34.6 \%$ & $29.0 \%$ & $40.0 \%$ & $-11.0 \%$ & -1.03 \\
\hline Daily Spending & average spend per day in KRW ( $\$ 1=$ approx. $1000 \mathrm{KRW})$ & 11750 & 11670 & 11830 & -160 & -0.14 \\
\hline Smoking & $\%$ of smokers & $11.5 \%$ & $5.3 \%$ & $17.5 \%$ & $-12.2 \%$ & $-1.69^{*}$ \\
\hline Exercise & $\%$ of subjects who exercise regularly & $39.7 \%$ & $39.5 \%$ & $40.0 \%$ & $-0.5 \%$ & -0.05 \\
\hline Risk-taking & $\begin{array}{c}\text { General attitude towards risk on a scale from } 1 \text { to } 3 \\
\text { ( } 3 \text { being the most risk-seeking) }\end{array}$ & 1.59 & 1.66 & 1.53 & 0.13 & 0.80 \\
\hline Trust & $\begin{array}{l}\text { General attitude towards trust on a scale from } 1 \text { to } 3 \\
\text { ( } 3 \text { being a lot of trust) }\end{array}$ & 1.45 & 1.34 & 1.55 & -0.21 & -1.33 \\
\hline Other Participants & $\begin{array}{c}\% \text { of subjects who knew other participants in same } \\
\text { or previous sessions }\end{array}$ & $41.0 \%$ & $29.0 \%$ & $52.5 \%$ & $-23.5 \%$ & $-2.11 * *$ \\
\hline Confidence & $\begin{array}{c}\% \text { of subjects who siad they were confident they would receive } \\
\text { payments as described in the instructions }\end{array}$ & $91.0 \%$ & $97.4 \%$ & $85.0 \%$ & $12.4 \%$ & $1.91 *$ \\
\hline Understand & $\%$ of subjects who said instructions were comprehensible & $98.7 \%$ & $97.4 \%$ & $100 \%$ & $-2.6 \%$ & -1.03 \\
\hline
\end{tabular}

$\underline{\text { Panel B: Time Preferences }}$

\begin{tabular}{|c|c|c|c|c|c|c|}
\hline Variable & Description & $\begin{array}{l}\text { Full sample } \\
\text { Mean }\end{array}$ & $\begin{array}{l}\text { Hard-earned } \\
\text { Mean }\end{array}$ & $\begin{array}{l}\text { Windfall } \\
\text { Mean }\end{array}$ & Mean Diff & $\mathrm{t}$ (or z)-stat \\
\hline Age & Subject's age in years & 20.9 & 21.0 & 20.8 & 0.2 & 0.283 \\
\hline Year & University year & 2.39 & 2.47 & 2.31 & 0.16 & 0.56 \\
\hline Gender & $\%$ of male subjects & $45.9 \%$ & $48.4 \%$ & $43.3 \%$ & $5.1 \%$ & 0.397 \\
\hline Course & $\%$ of subjects who are on business school related degree courses & $39.3 \%$ & $38.7 \%$ & $40 \%$ & $-1.3 \%$ & -0.103 \\
\hline Employment & $\%$ of subjects with employment history & $8.2 \%$ & $9.7 \%$ & $6.7 \%$ & $3.0 \%$ & 0.428 \\
\hline Daily Spending & average spend per day in $£$ & 8.48 & 8.60 & 8.37 & 0.23 & 0.131 \\
\hline Smoking & $\%$ of smokers & $13.1 \%$ & $6.45 \%$ & $20 \%$ & $-13.6 \%$ & -1.567 \\
\hline Exercise & $\%$ of subjects who exercise regularly & $68.9 \%$ & $61.3 \%$ & $76.7 \%$ & $-15.4 \%$ & -1.297 \\
\hline Risk-taking & $\begin{array}{l}\text { General attitude towards risk on a scale from } 1 \text { to } 3 \\
\text { ( } 3 \text { being the most risk-seeking) }\end{array}$ & 2.19 & 2.33 & 2.14 & 0.19 & 1.02 \\
\hline Trust & $\begin{array}{l}\text { General attitude towards trust on a scale from } 1 \text { to } 3 \\
\text { ( } 3 \text { being a lot of trust) }\end{array}$ & 1.66 & 1.7 & 1.62 & 0.08 & 0.41 \\
\hline Other Participants & $\begin{array}{c}\% \text { of subjects who knew other participants in same } \\
\text { or previous sessions }\end{array}$ & $27.9 \%$ & $32.3 \%$ & $23.3 \%$ & $9.0 \%$ & 0.778 \\
\hline Confidence & $\begin{array}{c}\% \text { of subjects who siad they were confident they would receive } \\
\text { payments as described in the instructions }\end{array}$ & $96.7 \%$ & $96.8 \%$ & $96.7 \%$ & $0.1 \%$ & 0.022 \\
\hline Understand & $\%$ of subjects who said instructions were comprehensible & $100 \%$ & $100 \%$ & $100 \%$ & - & - \\
\hline
\end{tabular}




\section{Continued ...}

\section{Panel A: Other Variables (Risk Preferences)}

\begin{tabular}{|c|c|c|c|c|c|c|}
\hline Variable & Description & $\begin{array}{l}\text { Full sample } \\
\text { Mean }\end{array}$ & $\begin{array}{l}\text { Hard-earned } \\
\text { Mean }\end{array}$ & $\begin{array}{l}\text { Windfall } \\
\text { Mean }\end{array}$ & Mean Diff & $\mathrm{t}($ or $\mathrm{z})$-stat \\
\hline Plagiarism & $\%$ of subjects who have at least once plagiarised coursework & $34.6 \%$ & $34.2 \%$ & $35.0 \%$ & $-0.08 \%$ & -0.07 \\
\hline Cheating & $\%$ of subjects who have at least once cheated on exam & $12.8 \%$ & $13.2 \%$ & $12.5 \%$ & $0.07 \%$ & 0.09 \\
\hline Postpone & $\%$ of subjects who said they often postpone duty & $66.7 \%$ & $63.2 \%$ & $70.0 \%$ & $-6.8 \%$ & -0.64 \\
\hline Drinking & $\%$ of subjects who drink at least once a week & $62.8 \%$ & $55.3 \%$ & $70.0 \%$ & $-14.7 \%$ & -1.22 \\
\hline Savings A/C & $\%$ of subjects with savings a/c & $62.8 \%$ & $71.1 \%$ & $55.0 \%$ & $16.1 \%$ & 1.45 \\
\hline Regular Savings & $\%$ of subjects who save regularly & $19.2 \%$ & $23.7 \%$ & $15.0 \%$ & $8.7 \%$ & 0.97 \\
\hline Lending & $\%$ of subjects who often lend money to others & $46.2 \%$ & $39.5 \%$ & $52.5 \%$ & $-13.0 \%$ & -1.15 \\
\hline Experience & $\%$ of subjects who have participated experiments before & $50.0 \%$ & $55.3 \%$ & $45.0 \%$ & $10.3 \%$ & 0.91 \\
\hline \multicolumn{7}{|c|}{ Panel B: Other Variables (Time Preferences) } \\
\hline Track & $\%$ of subjects who kept records of expenses & 20.9 & 21.0 & 20.8 & 0.2 & 0.14 \\
\hline Patience & $\begin{array}{c}\text { General level of patience on a scale from } 1 \text { to } 3 \\
\text { ( } 3 \text { being the most patient) }\end{array}$ & 2.19 & 2.20 & 2.17 & 0.03 & 0.14 \\
\hline Temptation & $\begin{array}{c}\text { General likelihood to succumb to temptation on a sacle from } 1 \text { to } 3 \\
\text { ( } 3 \text { being the most likely to resist temptation) }\end{array}$ & 2.19 & 2.23 & 2.14 & 0.09 & 0.91 \\
\hline Prent-Bias & $\%$ of subjects who were present biased in hypothetical question & $14.8 \%$ & $12.9 \%$ & $16.7 \%$ & $-3.8 \%$ & -0.42 \\
\hline Nationality & $\%$ of subjects who are based in the UK or Ireland & $27.9 \%$ & $29.0 \%$ & $26.7 \%$ & $2.3 \%$ & 0.21 \\
\hline Concern & $\begin{array}{l}\% \text { of subjects who had some specific reasons for their choices } \\
\text { (i.e., decision-making was not salient) }\end{array}$ & $19.7 \%$ & $19.4 \%$ & $20.0 \%$ & $-0.6 \%$ & -0.06 \\
\hline
\end{tabular}




\section{Table A2. Ordered Logit (Marginal Effects)}

The table reports the marginal effects of earning money on the probability of choosing each option $\operatorname{Pr}($ Option ' $\mathrm{i}$ ' $=1)$ in each problem from the ordered logit model, where each problem differ in the earlier date and the later date combination, ( $t$ days, $t+k$ days $) \in\{(0,42),(0,84),(0,126)$, $(42,84),(42,126),(42,168)\}$. The standard errors are in brackets and are clustered at an individual level. Asterisks next to the coefficients are levels of significance, denoting $*=p<0.10, * *=p<0.05$, and $* * *=p<0.01$.

\begin{tabular}{|c|c|c|c|c|c|c|}
\hline Choice (Y=Option' $\mathrm{i}$ ') & $\begin{array}{c}(1) \\
(0,42 \text { days })\end{array}$ & $\begin{array}{c}(2) \\
(0,84 \text { days })\end{array}$ & $\begin{array}{c}(3) \\
(0,126 \text { days })\end{array}$ & $\begin{array}{c}(4) \\
(42,84 \text { days })\end{array}$ & $\begin{array}{c}(5) \\
(42,126 \text { days })\end{array}$ & $\begin{array}{c}(6) \\
(42,168 \text { days })\end{array}$ \\
\hline Option 1 & $\begin{array}{c}-0.177 * * * \\
(0.0646)\end{array}$ & $\begin{array}{l}-0.171 * * \\
(0.0673)\end{array}$ & $\begin{array}{l}-0.124 * \\
(0.0637)\end{array}$ & $\begin{array}{c}-0.174 * * * \\
(0.0567)\end{array}$ & $\begin{array}{c}-0.191 * * * \\
(0.0643)\end{array}$ & $\begin{array}{c}-0.187 * * * \\
(0.0656)\end{array}$ \\
\hline Option 2 & $\begin{array}{l}-0.0146^{*} \\
(0.00886)\end{array}$ & $\begin{array}{l}-0.0135^{*} \\
(0.00725)\end{array}$ & $\begin{array}{l}-0.00620 \\
(0.00451)\end{array}$ & $\begin{array}{c}-0.0251 * * \\
(0.0123)\end{array}$ & $\begin{array}{l}-0.0174 * \\
(0.00944)\end{array}$ & $\begin{array}{l}-0.00599 \\
(0.00391)\end{array}$ \\
\hline Option 3 & $\begin{array}{l}-0.0192^{*} \\
(0.00991)\end{array}$ & $\begin{array}{l}-0.0144 * \\
(0.00839)\end{array}$ & $\begin{array}{l}-0.00431 \\
(0.00374)\end{array}$ & $\begin{array}{c}-0.0369 * * \\
(0.0177)\end{array}$ & $\begin{array}{c}-0.0267^{* *} \\
(0.0132)\end{array}$ & $\begin{array}{l}-0.00881 * \\
(0.00469)\end{array}$ \\
\hline Option 4 & $\begin{array}{l}-0.0105 \\
(0.00643)\end{array}$ & $\begin{array}{l}-0.00524 \\
(0.00484)\end{array}$ & $\begin{array}{l}-0.000295 \\
(0.00244)\end{array}$ & $\begin{array}{l}-0.0172 * \\
(0.0103)\end{array}$ & $\begin{array}{l}-0.0147^{*} \\
(0.00852)\end{array}$ & $\begin{array}{l}-0.00394 \\
(0.00343)\end{array}$ \\
\hline Option 5 & $\begin{array}{l}-0.00315 \\
(0.00307)\end{array}$ & $\begin{array}{l}-0.000756 \\
(0.00410)\end{array}$ & $\begin{array}{c}0.00102 \\
(0.00117)\end{array}$ & $\begin{array}{c}-0.0118 \\
(0.00779)\end{array}$ & $\begin{array}{c}-0.0111 \\
(0.00742)\end{array}$ & $\begin{array}{l}-0.000868 \\
(0.00215)\end{array}$ \\
\hline Option 6 & $\begin{array}{c}0.225 * * * \\
(0.0833)\end{array}$ & $\begin{array}{l}0.205^{* *} \\
(0.0825)\end{array}$ & $\begin{array}{c}0.134^{*} \\
(0.0701)\end{array}$ & $\begin{array}{c}0.265 * * * \\
(0.0896)\end{array}$ & $\begin{array}{c}0.261 * * * \\
(0.0888)\end{array}$ & $\begin{array}{c}0.207 * * * \\
(0.0731)\end{array}$ \\
\hline Observations & 354 & 354 & 354 & 354 & 354 & 354 \\
\hline
\end{tabular}




\section{Figure 1. The proportion of riskless Option A was chosen at each decision row}

The figure below displays the proportion of times Option A was chosen at each decision row for each group. The horizontal axis is the row number and vertical axis is the percentage of Option A was chosen. The blue line displays results for the windfall money group and the red line displays results for the hard-earned money group. The green line displays theoretical prediction of a risk-neutral individual.

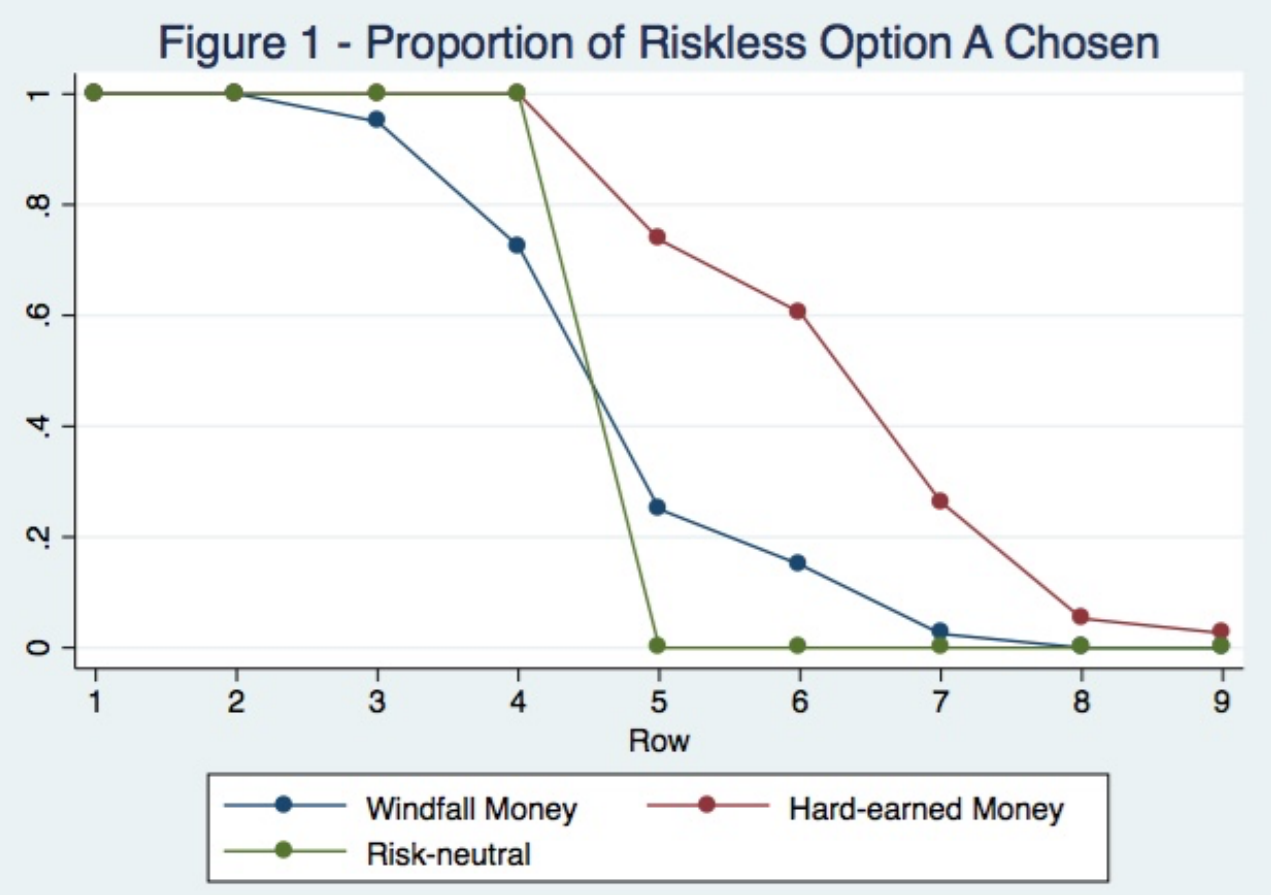




\section{Figure 2. Mean Allocation (Time-Preferences)}

The figure below displays the mean allocation of earned/endowed money to the LATER date against the daily interest rate (in basis points) for each group. As expected, subjects increase their allocation to the later date as the interest rate increases. The figure also shows that the mean number of allocation to the later date is higher in the hard-earned group than in the windfall group for a given interest rate, suggesting that subjects are more patient in the hard work group.

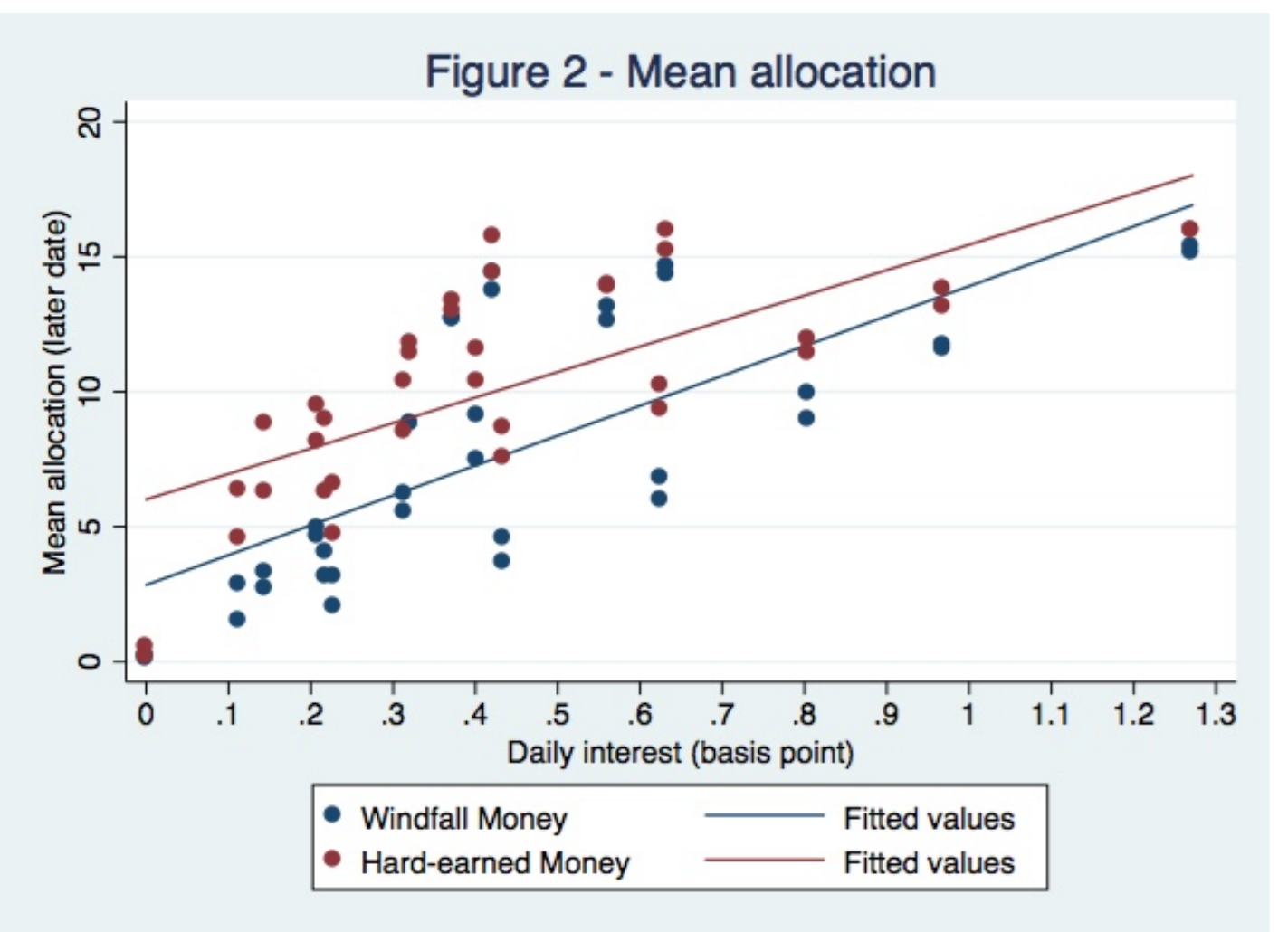




\section{Table A3. Heterogeneity of the effect of earning money (Risk choice)}

The table reports heterogeneity of the effect of earning money on individual risk choice from OLS. The dependent variable is the frequency with which riskless Option A was chosen. In order to observe which individual in the hard-earned group has more or less effect from earing money, we consider following interaction terms; Earned $\times$ Male is the interaction effect of males in the hard-earned group. Earned $\times$ Daily spending is the interaction effect of subjects in the hard-earned group whose average daily spending is high (i.e., upper quartile). Earned $\times$ Age is the interaction effect of subject's age in the hard-earned group. Earned $\times$ Course is the interaction effect of degree of course in the hard-earned group. Earned $\times$ Risk is the interaction effect of subject's general risk-taking in the hard-earned group. Earned $\times$ Trust is the interaction effect of subject's general level of trust in the hard-earned group. Earned $\times$ Drinking is the interaction effect of subject who drinks in the hard-earned group. Earned $\times$ Exercise is the interaction effect of subject who regularly exercise in the hard-earned group. Earned $\times$ Contraception is the interaction effect of subject's frequency of contraception in the hard-earned group. Earned $\times$ Regular is the interaction effect of regular savers in the hard-earned group. In Column (6), we also include some other demographic variables as in Table 1. The table reports coefficient and standard errors in brackets. Asterisks next to the coefficients are levels of significance of the estimates, denoting $*=p<0.10, * *=p<0.05$, and $* * *=p<0.01$.

\begin{tabular}{|c|c|c|c|c|c|c|}
\hline VARIABLES & $\begin{array}{c}(1) \\
\text { Model } \\
\end{array}$ & $\begin{array}{c}(2) \\
\text { Model } \\
\end{array}$ & $\begin{array}{c}(3) \\
\text { Model } \\
\end{array}$ & $\begin{array}{c}(4) \\
\text { Model } \\
\end{array}$ & $\begin{array}{c}(5) \\
\text { Model }\end{array}$ & $\begin{array}{c}(6) \\
\text { Model } \\
\end{array}$ \\
\hline Earned & $\begin{array}{c}1.958 * * * \\
(0.403)\end{array}$ & $\begin{array}{c}2.184 * * * \\
(0.429)\end{array}$ & $\begin{array}{l}1.465^{*} \\
(0.797)\end{array}$ & $\begin{array}{c}2.297 * * \\
(1.024)\end{array}$ & $\begin{array}{l}2.436^{*} \\
(1.235)\end{array}$ & $\begin{array}{l}2.694^{*} \\
(1.421)\end{array}$ \\
\hline Gender ( $=1$ if Male) & $\begin{array}{l}-0.167 \\
(0.372)\end{array}$ & $\begin{array}{l}-0.192 \\
(0.371)\end{array}$ & $\begin{array}{l}-0.225 \\
(0.379)\end{array}$ & $\begin{array}{l}-0.218 \\
(0.379)\end{array}$ & $\begin{array}{c}-0.186 \\
(0.394)\end{array}$ & $\begin{array}{l}-0.0913 \\
(0.464)\end{array}$ \\
\hline Earned $\times$ Male & $\begin{array}{l}-0.549 \\
(0.536)\end{array}$ & $\begin{array}{l}-0.499 \\
(0.536)\end{array}$ & $\begin{array}{l}-0.460 \\
(0.564)\end{array}$ & $\begin{array}{l}-0.348 \\
(0.563)\end{array}$ & $\begin{array}{l}-0.471 \\
(0.595)\end{array}$ & $\begin{array}{l}-0.867 \\
(0.628)\end{array}$ \\
\hline Daily spending (=1 if High) & & $\begin{array}{c}0.616 \\
(0.403)\end{array}$ & $\begin{array}{c}0.616 \\
(0.425)\end{array}$ & $\begin{array}{c}0.641 \\
(0.423)\end{array}$ & $\begin{array}{c}0.267 \\
(0.484)\end{array}$ & $\begin{array}{c}0.208 \\
(0.466)\end{array}$ \\
\hline Earned $\times$ Daily spending & & $\begin{array}{l}-0.835 \\
(0.575)\end{array}$ & $\begin{array}{l}-0.786 \\
(0.599)\end{array}$ & $\begin{array}{l}-0.738 \\
(0.595)\end{array}$ & $\begin{array}{l}-0.255 \\
(0.653)\end{array}$ & $\begin{array}{l}-0.0656 \\
(0.629)\end{array}$ \\
\hline Age & & & $\begin{array}{l}-0.229 \\
(0.250)\end{array}$ & $\begin{array}{l}-0.194 \\
(0.258)\end{array}$ & $\begin{array}{c}0.108 \\
(0.298)\end{array}$ & $\begin{array}{c}0.497 \\
(0.401)\end{array}$ \\
\hline Earned $\times$ Age & & & $\begin{array}{c}0.419 \\
(0.350)\end{array}$ & $\begin{array}{c}0.511 \\
(0.364)\end{array}$ & $\begin{array}{c}0.227 \\
(0.402)\end{array}$ & $\begin{array}{c}0.308 \\
(0.433)\end{array}$ \\
\hline Course & & & $\begin{array}{c}0.255 \\
(0.403)\end{array}$ & $\begin{array}{c}0.268 \\
(0.406)\end{array}$ & $\begin{array}{c}0.356 \\
(0.406)\end{array}$ & $\begin{array}{c}0.470 \\
(0.433)\end{array}$ \\
\hline Earned $\times$ Course & & & $\begin{array}{l}-0.531 \\
(0.607)\end{array}$ & $\begin{array}{l}-0.610 \\
(0.612)\end{array}$ & $\begin{array}{c}-0.613 \\
(0.621)\end{array}$ & $\begin{array}{l}-0.868 \\
(0.640)\end{array}$ \\
\hline Risk-taking & & & & $\begin{array}{l}-0.190 \\
(0.305)\end{array}$ & $\begin{array}{c}0.124 \\
(0.328)\end{array}$ & $\begin{array}{l}-0.206 \\
(0.342)\end{array}$ \\
\hline Earned $\times$ Risk-taking & & & & $\begin{array}{r}-0.0975 \\
(0.391)\end{array}$ & $\begin{array}{l}-0.439 \\
(0.420)\end{array}$ & $\begin{array}{l}-0.285 \\
(0.432)\end{array}$ \\
\hline Trust & & & & $\begin{array}{c}4.40 \mathrm{e}-05 \\
(0.250)\end{array}$ & $\begin{array}{c}0.183 \\
(0.289)\end{array}$ & $\begin{array}{l}-0.0884 \\
(0.289)\end{array}$ \\
\hline Earned $\times$ Trust & & & & $\begin{array}{l}-0.667 \\
(0.435)\end{array}$ & $\begin{array}{c}-0.990 * * \\
(0.487)\end{array}$ & $\begin{array}{l}-0.863^{*} \\
(0.506)\end{array}$ \\
\hline Drinking & & & & & $\begin{array}{l}-0.109 \\
(0.461)\end{array}$ & $\begin{array}{l}-0.195 \\
(0.446)\end{array}$ \\
\hline Earned $\times$ Drinking & & & & & $\begin{array}{c}0.407 \\
(0.624)\end{array}$ & $\begin{array}{c}0.200 \\
(0.654)\end{array}$ \\
\hline Exercise & & & & & $\begin{array}{l}-0.721 \\
(0.488)\end{array}$ & $\begin{array}{l}-0.913^{*} \\
(0.501)\end{array}$ \\
\hline Earned $\times$ Exercise & & & & & $\begin{array}{c}0.882 \\
(0.642)\end{array}$ & $\begin{array}{l}1.417 * * \\
(0.649)\end{array}$ \\
\hline Contraception & & & & & $\begin{array}{c}-0.476^{*} \\
(0.254)\end{array}$ & $\begin{array}{l}-0.236 \\
(0.273)\end{array}$ \\
\hline Earned $\times$ Contraception & & & & & $\begin{array}{c}0.375 \\
(0.346)\end{array}$ & $\begin{array}{c}0.125 \\
(0.339)\end{array}$ \\
\hline Regular savers & & & & & $\begin{array}{c}-0.374 \\
(0.623)\end{array}$ & $\begin{array}{l}0.0896 \\
(0.627)\end{array}$ \\
\hline Earned $\times$ Regular savers & & & & & $\begin{array}{c}0.132 \\
(0.791)\end{array}$ & $\begin{array}{l}-0.396 \\
(0.801)\end{array}$ \\
\hline
\end{tabular}


Year

Smoking

Employment

Plagiarism

Cheating

Postpone

Others

Confidence

Experience

Constant
$-0.252$

$(0.219)$

$-0.291$

$(0.558)$

0.0485

$(0.495)$

$-0.480$

$(0.365)$

$-0.0946$

(0.488)

$0.720^{* *}$

$(0.322)$

$0.709 * *$

$(0.348)$

$-0.906$

$(0.593)$

$-0.249$

$(0.359)$

$4.575^{* * *}$

(1.118)
$4.656^{* * *}$

(0.878)

78

0.439 


\section{Table A4. Heterogeneity of the effect of earning money (Intertemporal choice)}

The table reports heterogeneity of the effect of earning money on individual intertemporal choice from OLS. The dependent variable is the allocation to the later date. In order to observe which individuals in the hard-earned group has more or less effect from earing money, we consider following interaction terms; Earned $\times$ Male is the interaction effect of males in the hard-earned group. Earned $\times$ Daily spending is the interaction effect of subjects in the hard-earned group whose average daily spending is high (i.e., upper quartile). Earned $\times$ Age is the interaction effect of subject's age in the hard-earned group. Earned $\times$ Course is the interaction effect of degree of course in the hard-earned group. Earned $\times$ Patience is the interaction effect of subject's general degree of patience in the hard-earned group. Earned $\times$ Temptation is the interaction effect of subject's general level of resisting temptation in the hard-earned group. Earned $\times$ Trust is the interaction effect of subject's general level of trust in the hard-earned group. Earned $\times$ Track is the interaction effect of subject who track expenses in the hard-earned group. Earned $\times$ Exercise is the interaction effect of subject who regularly exercise in the hard-earned group. In Column (6), we also include some other demographic variables as in Table 3. The table reports coefficient and standard errors in brackets, where standard errors are clustered at individual level. Asterisks next to the coefficients are levels of significance of the estimates, denoting $*=p<0.10, * *=p<0.05$, and $* * *=p<0.01$.

\begin{tabular}{|c|c|c|c|c|c|c|}
\hline VARIABLES & $\begin{array}{c}(1) \\
\text { Model } \\
\end{array}$ & $\begin{array}{c}(2) \\
\text { Model } \\
\end{array}$ & $\begin{array}{c}(3) \\
\text { Model } \\
\end{array}$ & $\begin{array}{c}(4) \\
\text { Model } \\
\end{array}$ & $\begin{array}{c}(5) \\
\text { Model } \\
\end{array}$ & $\begin{array}{c}(6) \\
\text { Model }\end{array}$ \\
\hline Earned & $\begin{array}{c}2.514 * * * \\
(0.944)\end{array}$ & $\begin{array}{c}2.161 * * \\
(0.976)\end{array}$ & $\begin{array}{c}4.048 * * * \\
(1.307)\end{array}$ & $\begin{array}{c}4.952 \\
(5.005)\end{array}$ & $\begin{array}{c}5.352 \\
(4.414)\end{array}$ & $\begin{array}{c}6.054 \\
(3.727)\end{array}$ \\
\hline Gender (=1 if Male) & $\begin{array}{l}-1.550 \\
(1.359)\end{array}$ & $\begin{array}{l}-1.481 \\
(1.387)\end{array}$ & $\begin{array}{l}-1.556 \\
(1.385)\end{array}$ & $\begin{array}{l}-1.681 \\
(1.415)\end{array}$ & $\begin{array}{l}-1.125 \\
(1.744)\end{array}$ & $\begin{array}{c}0.553 \\
(1.678)\end{array}$ \\
\hline Earned $\times$ Male & $\begin{array}{l}0.0141 \\
(1.837)\end{array}$ & $\begin{array}{l}-0.0683 \\
(1.859)\end{array}$ & $\begin{array}{l}-0.698 \\
(1.851)\end{array}$ & $\begin{array}{l}-0.645 \\
(1.895)\end{array}$ & $\begin{array}{l}-1.260 \\
(2.163)\end{array}$ & $\begin{array}{l}-2.268 \\
(1.962)\end{array}$ \\
\hline Daily spending (=1 if High) & & $\begin{array}{l}-0.964 \\
(1.452)\end{array}$ & $\begin{array}{l}-2.239 \\
(1.504)\end{array}$ & $\begin{array}{l}-2.183 \\
(1.520)\end{array}$ & $\begin{array}{l}-2.343 \\
(1.431)\end{array}$ & $\begin{array}{c}-2.550 * * \\
(1.244)\end{array}$ \\
\hline Earned $\times$ Daily spending & & $\begin{array}{l}1.157 \\
(2.056)\end{array}$ & $\begin{array}{l}2.915 \\
(2.082)\end{array}$ & $\begin{array}{c}2.815 \\
(2.034)\end{array}$ & $\begin{array}{c}2.926 \\
(1.987)\end{array}$ & $\begin{array}{c}2.542 \\
(1.922)\end{array}$ \\
\hline Age & & & $\begin{array}{l}-0.423 \\
(1.381)\end{array}$ & $\begin{array}{l}-0.734 \\
(1.379)\end{array}$ & $\begin{array}{l}-1.319 \\
(1.469)\end{array}$ & $\begin{array}{l}-3.237^{*} \\
(1.715)\end{array}$ \\
\hline Earned $\times$ Age & & & $\begin{array}{l}-0.287 \\
(1.838)\end{array}$ & $\begin{array}{c}0.108 \\
(1.755)\end{array}$ & $\begin{array}{c}0.799 \\
(1.808)\end{array}$ & $\begin{array}{l}3.489 * \\
(1.976)\end{array}$ \\
\hline Course & & & $\begin{array}{l}3.106^{* *} \\
(1.338)\end{array}$ & $\begin{array}{c}3.609 * * \\
(1.417)\end{array}$ & $\begin{array}{c}3.601 * * \\
(1.371)\end{array}$ & $\begin{array}{c}4.109 * * * \\
(1.299)\end{array}$ \\
\hline Earned $\times$ Course & & & $\begin{array}{c}-5.125 * * * \\
(1.858)\end{array}$ & $\begin{array}{c}-5.932 * * * \\
(1.843)\end{array}$ & $\begin{array}{c}-5.953 * * * \\
(1.886)\end{array}$ & $\begin{array}{c}-4.531 * * * \\
(1.627)\end{array}$ \\
\hline Patience & & & & $\begin{array}{l}0.0736 \\
(0.977)\end{array}$ & $\begin{array}{l}0.0541 \\
(0.898)\end{array}$ & $\begin{array}{l}0.0700 \\
(1.004)\end{array}$ \\
\hline Earned $\times$ Patience & & & & $\begin{array}{c}-0.845 \\
(1.294)\end{array}$ & $\begin{array}{l}-1.134 \\
(1.213)\end{array}$ & $\begin{array}{l}-1.933 \\
(1.245)\end{array}$ \\
\hline Temptation & & & & $\begin{array}{c}0.246 \\
(0.718)\end{array}$ & $\begin{array}{c}0.539 \\
(0.878)\end{array}$ & $\begin{array}{c}0.401 \\
(0.934)\end{array}$ \\
\hline Earned $\times$ Temptation & & & & $\begin{array}{l}-0.454 \\
(1.008)\end{array}$ & $\begin{array}{l}-0.636 \\
(1.153)\end{array}$ & $\begin{array}{l}-0.199 \\
(1.256)\end{array}$ \\
\hline Trust & & & & $\begin{array}{l}-1.153^{*} \\
(0.684)\end{array}$ & $\begin{array}{l}-1.029 \\
(0.823)\end{array}$ & $\begin{array}{l}-1.591^{*} \\
(0.942)\end{array}$ \\
\hline Earned $\times$ Trust & & & & $\begin{array}{c}1.281 \\
(1.080)\end{array}$ & $\begin{array}{c}1.009 \\
(1.130)\end{array}$ & $\begin{array}{c}0.219 \\
(1.149)\end{array}$ \\
\hline Track & & & & & $\begin{array}{l}-0.486 \\
(1.160)\end{array}$ & $\begin{array}{c}2.031 \\
(1.329)\end{array}$ \\
\hline Earned $\times$ Track & & & & & $\begin{array}{l}-0.382 \\
(1.652)\end{array}$ & $\begin{array}{l}-3.271^{*} \\
(1.682)\end{array}$ \\
\hline Exercise & & & & & $\begin{array}{l}-1.465 \\
(1.894)\end{array}$ & $\begin{array}{l}-3.745^{*} \\
(2.008)\end{array}$ \\
\hline Earned $\times$ Exercise & & & & & $\begin{array}{c}1.573 \\
(2.255)\end{array}$ & $\begin{array}{c}3.841 \\
(2.342)\end{array}$ \\
\hline Year & & & & & & $\begin{array}{l}0.0835 \\
(0.624)\end{array}$ \\
\hline Smoking & & & & & & $\begin{array}{c}-0.412 \\
(1.380)\end{array}$ \\
\hline & & ed on $n$ & & & & \\
\hline
\end{tabular}


Present-bias

Risk-taking

Nationality

Others

(0.924)

$-2.545^{* *}$

(0.994)

Reason

Price ratio

$$
\begin{gathered}
19.44 * * * \\
(0.994) \\
-18.30 * * * \\
(1.470)
\end{gathered}
$$

$19.44 * * *$

Constant

(0.994)

$-18.00 * * *$

(1.563)

$19.44 * * *$
$(0.995)$
$-18.61 * * *$
$(1.508)$

$19.44 * * *$

(0.997)

$-17.45 * * *$

$19.44 * * *$

(0.998)

(3.239)

$-16.80 * * *$

(2.964)

$-4.608 * * *$

(1.180)

$19.44 * * *$

(0.999)

$-13.27 * * *$

Observations

2,124

2,124

2,124

2,124

2,124

0.490

2,124

0.487

0.565 